\title{
The Accademia degli Alterati and the Invention of a New Form of Dramatic Experience: Myth, Allegory, and Theory in Jacopo Peri's and Ottavio Rinuccini's Euridice (160o)*
}

\author{
Déborah Blocker
}

On the evening of 6 October 16oo, as part of the week-long festivities celebrating the wedding by proxy of Maria de' Medici and Henry IV of France, a new type of divertimento was staged inside the Pitti Palace in Florence. The performance was given in the apartments of Don Antonio de' Medici (1576-1621) for the enjoyment of the official wedding guests of Grand Duke Ferdinando I de' Medici (1549-1609), as well as a small number of Florentine courtiers. The piece was a poetic text set to music, staging a happy-ended version of the myth of Orpheus and Eurydice in stile recitativo. It bore the title Euridice and is often considered today to have constituted the first courtly opera. The performance also included an element that is usually absent from most modern operas: it was enhanced by ballets, sometimes involving the whole cast, as during the finale. ${ }^{1}$ Euridice's libretto had been composed by the poet Ottavio Rinuccini (1562-1621), while the music was a creation of Jacopo Peri (1561-1633), both artists having worked in close collaboration with their patron, the Florentine merchant and music lover Jacopo Corsi (1561-1602). Corsi had financed and organised most of the court performance and went so far as to play the harpsichord to support the efforts of his protégés during the event. These men were not only tied by bonds of patronage and friendship; they were also tightly

\footnotetext{
* I am very grateful to Tim Carter for his thorough comments on one of the last drafts of this essay. I also thank Anne Piéjus for her detailed remarks on the initial conference paper.

1 Tim Carter, 'Epyllia and Epithalamia: Some Narratives Frames for Early Opera', forthcoming, p. 17 , also underscores that the performance was followed by two hours of communal court dancing. See Angelo Solerti, Musica, ballo e drammatica alla corte Medicea dal 1600 al 1637; notizie tratte da un diario, con appendice di testi inediti e rari (Florence: R. Bemporad \& Figlio, 1905), p. 25, n. 1, where the Ambassador of Parma is quoted as having reported that after the performance 'poi si ballò piu di due ore, mesticate la Regina e l'altre principesse con le private, et si fini la festa'.
} 
connected by their links to one of the major learned societies of late Renaissance Florence, the Accademia degli Alterati (1560-c. 1625), whose discussions on the pleasures of art and on the effects of dramatic spectacles may well have been the basis for many of the novelties of Euridice.

In what follows, the central aim is to better understand what these three men were trying to accomplish, both at the artistic level and in social and political terms, with the production of this new type of dramatic experience at the Florentine court. The study begins by documenting the particular circumstances in which the work was originally produced in order to support the subsequent investigation of two main lines of inquiry. The first of these is the question of what types of pleasure(s) this spectacle attempted to generate as well as that of what forms of both sensual and spiritual experience the divertimento's creators sought to make accessible to their audience. Because Euridice proposes nothing less than a self-reflexive representation of the types of experience it strives, as a performance, to offer, these questions can be elucidated by studying how the primary features of the spectacle created by Rinuccini, Peri, and Corsi were exhibited, in an allegorical mode, within the work itself. Once the nature of the new artistic experience being experimented with in Euridice is defined, it becomes possible to ask a second question, which is equally central to the work's allegorical plot: what is the place of the pleasures generated by art in a well-ordered polity? Because of the particular circumstances of Euridice's performance, this question is, more specifically, how the spiritual pleasures of art's materiality can be both produced and enjoyed in the context of an authoritarian regime, such as that of the Medici. The responses Euridice ventures to these two sets of questions shed new light on our historical understanding of Renaissance drama and poetics alike-showing how, in specific circumstances, reflections on the pleasures of art could reflexively constitute the core of a dramaturgical production as well as how, within court culture itself, forms of autonomy were experimented with and even asserted within such productions, despite the constraints the patronage system is sometimes believed to have imposed upon artists.

\section{Was Euridice the Covert Dramaturgical Manifesto of a Nonconformist Academy?}

Peri's and Rinuccini's Euridice has recently received quite a bit of scholarly attention, ${ }^{2}$ but many of the most central elements in the history of its creation

2 Angelo Solerti, Gli Arbori del Melodramma, 3 vols (Milan: R. Sandron, 1904), II (on Ottavio Rinuccini), pp. 105-42 offers the first modern printing of the libretto. Claude Palisca's work 
remain unclear. Particularly puzzling is the fact that the work, despite having been staged as part of the festivities celebrating Maria de' Medici's wedding, seems to contain very little explicit praise of the Medici. One of the work's most recent interpreters, music historian Gaspare De Caro, suggests that although it may not directly eulogise the Medici, the opera does celebrate Florence's new alliance with France, which the Florentine patriciate had enthusiastically welcomed. He also brings to light a historical element that had hitherto been neglected, by strongly emphasising Rinuccini's and his patron Corsi's ties to the Accademia degli Alterati, whose attitude towards the Medici regime was frequently ambivalent. ${ }^{3}$ However, because no full-length study currently exists on the Alterati, ${ }^{4}$ whose activities were so secretive that very few of their writings

was instrumental in bringing to light the context in which the work was first performed, in particular in his 'The First Performance of Euridice', originally published in Twenty-Fifth Anniversary Festschrift, ed. by Albert Mell (New York: Queens College Press, 1964), pp. 1-24, and republished in his Studies in the History of Italian Music and Music Theory (Oxford: Clarendon Press, 1994), pp. 432-51. (Page references to this essay are to the 1964 original publication.) Tim Carter, 'Jacopo Peri's Euridice (160o): A Contextual Study', The Musical Review, 43 (1982), pp. 83-103, proposes a contextual analysis of the creation of Euridice which highlights the intense artistic rivalries of which this work was a product; reprinted in Tim Carter, Music, Patronage and Printing in Late Renaissance Florence (Farnham: Ashgate Publishing Limited, 2000), part III. Bojan Bujic, 'Figura Poetica Molto Vaga: Structure and Meaning in Rinuccini's Euridice', Early Music History, 10 (1991), pp. 29-64, prefers to understand this opera as an allegorical representation of Florence's success in renewing its alliance with the French crown. La Naissance de l'opéra: Euridice, 1600-200o, ed. by Françoise Decroisette, Françoise Graziani, and Joël Heuillon (Paris: L'Harmattan, 2001), focuses on Euridice's contributions to the development of modern musical spectacle via a post-humanist reworking of the tragic model inherited from Greek antiquity. Kelley Harness, 'Le tre Euridici: Characterization and Allegory in the Euridici of Peri and Caccini', Journal of Seventeenth Century Music, 9.1 (2003): $<\mathrm{http}$ ///www.sscm-jscm.org/vg/no1/harness.html >, concedes that Euridice 'did not follow the traditional path of encomiastic spectacle', making no 'direct references to the bridal couple' and offering no explicit praise of Ferdinando; she nonetheless persists in reading the opera as an allegory of Medici power ( $\$ 7.1$ to 7.5 ).

3 Gaspare De Caro, Momenti dell'umanesimo civile fiorentino (Bologna: Ut Orpheus Edizioni, 2006), pp. 117-84.

4 Scholarship on this institution remains scattered. See in particular Bernard Weinberg, 'The Accademia degli Alterati and Literary Taste from 1570 to 1600', Italica, 31.4 (1954), pp. 207-14, and 'Argomenti di discussione letteraria nell'Accademia degli Alterati (1570-1600)', Giornale storico della letteratura italiana, 131 (1954), pp. 175-94; Claude Palisca, "The Alterati of Florence: Pioneers in the Theory of Dramatic Music' (1968), in Studies in the History of Italian Music and Music Theory (Oxford: Clarendon Press, 1994), pp. 408-31; Eric Cochrane, Florence in the Forgotten Centuries, 1527-180o (Chicago: University of Chicago Press, 1973), pp. 93-161; Michel Plaisance, L'Accademia e il suo Principe: cultura e politica a Firenze al tempo di Cosimo I e di Francesco de' Medici. L'Académie et le Prince: culture et politique à Florence au 
made it into print during the lifetime of the institution, De Caro's book falls short of uncovering just how closely related the plot of Euridice might have been to many of the central interests and theories of the academy's members. This essay picks up where De Caro left off, with the aim of providing a carefully historicised framework within which the stakes of Euridice's allegorical discourse can be exposed.

\subsection{Corsi, Peri, and Rinuccini: Providers of a New Type of Court Spectacle} It has long been established that the driving force behind the staging of Euridice during the celebration of Maria de' Medici's elevation to the throne of France was the very same man whose money and social connections had made the prestigious alliance possible in the first place, namely the powerful Florentine merchant and patron Jacopo Corsi. ${ }^{5}$ Corsi came from a family that had had ties to anti-Medici factions during the fall of the Florentine Republic. His forefathers had, at one time, been in a rather mediocre financial situation. By the end of the sixteenth century, however, they were among the wealthiest merchant families in town. Corsi's wealth put him in a position to play a major role in the diplomatic negotiations which led to the marriage of Maria de' Medici. Indeed, it was he who rallied the Florentine nobiltà around Ferdinando's marriage project, convincing his peers to help finance the enormous dowry Henry was demanding, and presumably himself volunteering a large sum to make the wedding possible. ${ }^{6}$ Once the marriage had been agreed to, Corsi

temps de Côme Ier et de François de Medicis (Manziana, Rome: Vecchiarelli, 2004), pp. 363404; Anna Siekiera, 'Il volgare nell'Accademia degli Alterati', in Italia linguistica: discorsi di scritto e di parlato: nuovi studi di linguistica italiana per Giovanni Nencioni, ed. by Marco Bifi, Omar Calabrese, and Luciana Salibra (Siena: Protagon, 2005), pp. 87-112; and Henk Th. van Veen, 'The Accademia degli Alterati and Civic Virtue', in The Reach of the Republic of Letters: Literary and Learned Societies in Late Medieval and Early Modern Europe, ed. by Arian Van Dixhoorn and Susie Speakman Sutch, 2 vols (Leiden: Brill, 2008), II, pp. 285-308.

5 On Jacopo Corsi, see in particular Tim Carter, 'Music and Patronage in Late SixteenthCentury Florence: The Case of Jacopo Corsi (1561-1602)', I Tatti Studies in the Renaissance, 1 (1985), pp. 57-104 (reprinted in Carter, Music, Patronage and Printing in Late Renaissance Florence, part VII). See also Paolo Malanima's article in the Dizionario biografico degli italiani, or DBI (vol. XxIx, 1983): <http://www.treccani.it/enciclopedia/ iacopo-corsi_res-5512502d-87eb-11dc-8egd-oo16357eee51_(Dizionario-Biografico)>.

6 The source most often cited is Jacopo Galluzzi, Istoria del Granducato di Toscana sotto il Governo della Casa Medici (Florence: Gaetano Cambiagi, 1781), v, p. 321: 'informato delle pendenti contestazioni sulla quantità della dote, ebbe il coraggio di supplicare il Gran Duca a nome dei suoi concittadini di desistere dalle opposizioni e offerire le ricchezze di ciascheduno per contribuire alla dote richiesta.' Archival sources probably exist but do not seem to have yet been brought to light. 
continued to display his support for the Medici's hard-won new alliance by financing a large share of the staging of Euridice during the celebrations. The official descrizione of the festivities underscores this fact, portraying Euridice as the sumptuous gift of a private nobleman to the newlyweds. ${ }^{7}$ Archival research has however shown that the court provided some of the musicians and part of the scenery. ${ }^{8}$ It is nonetheless clear that not only did Corsi fund the performance in a substantial way, in particular with regard to the costly costumes: he also coordinated its creation and production. One could therefore compare his role in the celebrations to that of the chorêgos in ancient Athens- that is of the wealthy citizen who assumed the public duty of financing the preparation for the chorus and other aspects of a dramatic production that were not paid for by the government of the polis. As such, it would have been uncivil and even inhospitable for the Medici household not to assist him financially and even artistically: they needed to show their munificence in this association, as they would have in any other court activity. But Corsi was clearly given the high hand on the form and contents of the performance, which was thought of and advertised as his private contribution, and not treated on par with those parts of the celebrations which were funded exclusively on court funds and

7 Michelangelo Buonarroti, Descrizione delle fellicissime nozze della cristianissima maestà di madama Maria Medici regina di Francia e di Navarra (Florence: Giorgio Marescotti, 16oo), [p. 22]: 'Il perche appresso le nozze in tutti quei giorni, che precederono alla partenza del Legato, e della Regina, vari trattenimenti si tennero, e della corte non solamente. Ma mentre che i più magnanimi spettacoli si andavano apprestando: per maggiore contentezza, e più universale mostrarsi, eziamdio de i nobili, e suntuosi da' particulari, e magnanimi gentilhuomini ne furono ordonati. La onde avendo il Signor Jacopo Corsi fatta mettere in musica con grande studio la Euridice affetuosa, e gentilissima favola del Signor Ottavio Rinuccini, e per li personnagi, richissimi, e belli vestimenti apprestati; offertala a loro Altezze; fu ricevuta, e preparatale nobile scena nel Palazzo Pitti: e la sera seguente a quelle delle reali nozze rappresentata.'

8 Richard A. Goldthwaite and Tim Carter, Orpheus in the Marketplace: Jacopo Peri and the Economy of Late Renaissance Florence (Cambridge: Harvard University Press, 2013), p. 112, stress that Ferdinando de Medici assisted generously with the performance: 'Yet, in the case of Euridice, despite Buonarroti's emphasis on Corsi as its provider, it is now clear that the court was significantly involved in the production and therefore in some sense supported Corsi's intentions for it. Not only did the court allow the participation of its singers, and those invited from the outside [...]; it also contributed by way of the grand-ducal Guardaroba (the Wardrobe), which among other things paid for the scenery designed by the Florentine artist Lodovico Cardi-Cigoli.' Tim Carter was also able to document at least some of Corsi's contribution to the costumes: see Tim Carter, Jacopo Peri, 1561-1633: His Life and Works, 2 vols (New York: Garland Publishing, 1989), I, p. 43, n. 114. 
placed under the direction of Ferdinando's superintendant of the arts, Emilio de' Cavalieri (1550-1602).

As a consequence, though the opera was part of the official series of wedding festivities, its function within them remained to a certain extent marginal. In particular, Euridice had a much more restricted audience than Giulio Caccini's Il Rapiamento di Cefalo, which was paid for in full by Ferdinando and was scheduled as the central divertimento of the series. ${ }^{9}$ This hierarchy was materialised by the venues attributed to each spectacle: Euridice was performed in a reception room of Don Antonio de' Medici's apartments in the Pitti Palace, ${ }^{10}$ while the Rapiamento was staged in the Uffizi theatre, the court's formal playhouse. ${ }^{11}$ Don Antonio was the son of Francesco I de' Medici (1541-1587) and his mistress (and soon to be wife) Bianca Cappello (1548-1587). He had been legitimised and could possibly have become Grand Duke after the death of his father, had Ferdinando not managed to impose himself as Francesco's legitimate successor. Don Antonio's position at court was in many ways a marginal one ${ }^{12}$ and the choice of his apartments to stage Euridice suggests that, at Ferdinando's court, Peri, Rinuccini, and Corsi were somewhat eccentric themselves. Had they not been, they might have been allotted a more central venue with more decorum. It is possible that, given Corsi's pivotal role in finding the funds necessary to finalise the wedding arrangements, the Medici could not have turned down his gift of a performance: in exchange for his financial support, this patron of the arts may therefore have been given the opportunity to introduce the music he favoured into the Medici court—on the condition that it not occupy centre stage.

Peri and Rinuccini had been under Corsi's patronage for several years when Euridice was conceived. Rinuccini came from a wealthy and powerful patrician family that had long opposed the Medici's rise to prominence. His career as court poet and librettist was launched in 1589 , when he was called upon to write several of the intermedi of La Pellegrina, the splendid spectacle performed in celebration of the marriage of Ferdinando with Christina of

Unlike Euridice, the music of Il Rapiamento di Cefalo is mostly lost. See Tim Carter, 'Rediscovering the Rapiamento di Cefalo',Journal of Seventeenth-Century Music, 9.1 (2003), available at $<$ http://www.sscm-jscm.org/vg/nol/carter.html $>$.

The rooms assigned to Don Antonio were in the southern wing of the second floor of the Pitti Palace. His apartment was adjacent to what later became known as the Salone delle Commedie (a large chamber housing the Grooms' Chamber, the small Ballroom, and the Music Room), in which Euridice was most probably staged.

11 Claude Palisca, 'The First Performance of Euridice', p. 4.

12 Filippo Luti, Don Antonio de' Medici e i suoi tempi (Florence: Leo S. Olschki, 2006). 
Lorraine (1565-1637) ${ }^{13}$ Peri came from a less prestigious family but could claim to be a nobile fiorentino by birth. ${ }^{14} \mathrm{He}$ had worked as a musician since his earliest years, mainly as a composer and singer of devotional music. ${ }^{15}$ It is only from 1588 that we find him mentioned in Ferdinando's household records as a court musician. ${ }^{16}$ His first noted appearance as a singer in a court divertimento was during the performance of La Pellegrina, where Peri-known as Il Zazzerino when performing - sung the role of the dithyramb Arion, an incarnation of the power of poetry and music, and a prefiguration of Peri's triumph as Orfeo in Euridice.

Euridice was conceived of and performed at a moment where rivalries amongst musicians and performers at Ferdinando's court were at their height. The central issue was the Roman Emilio de' Cavalieri's domination over the production of court festivities. Cavalieri's prior experience had primarily involved the production of devotional music for the Roman Oratory. After following Ferdinando to Florence in 1588, Cavalieri became the superintendent of artists, craftsmen, and musicians at court. ${ }^{17}$ As such, he organised the 1589 festivities and was also the overseer of the annual carnival productions. By 1600 , however, Cavalieri's position was threatened by a number of rivals-in particular Giulio Caccini (1551-1618), another musician of Roman origin, who had regularly laboured for the Medici since the mid-156os. Caccini was fired from the court musicians in 1593 (because of a dispute with Antonio Salviati) and used the 1600 festivities to get back into service. During these celebrations, he seems to have attained both his reintegration and Cavalieri's departure, which he achieved not only by intervening heavily in the staging, singing, and even

13 On this production and on Peri's and Rinuccini's participation in it, see Nina Treadwell, Music and Wonder at the Medici Court: The 1589 Interludes for 'La Pellegrina' (Bloomington: Indiana University Press, 2008), pp. 157-58, 209-14.

14 On Peri, see Tim Carter, 'Jacopo Peri', Music \& Letters, 61 (1980), pp. 121-35, reprinted in Carter, Music, Patronage and Printing in Late Renaissance Florence, part II; Carter, Jacopo Peri, 1561-1633; and Goldthwaite and Carter, Orpheus in the Marketplace, in particular pp. 2-10, which contain a survey of the historiography on Peri.

15 At court, Emilio de' Cavalieri attempted more than once to reduce Peri to the status of singer and writer of devotional music: see Goldthwaite and Carter, Orpheus in the Marketplace, p. 257.

16 However, Peri is found associated with the court and the Medici princesses as early as 1583 (under Francesco I), as an occasional musician, paid from the private funds of various members of the ruling family.

17 See Warren Kirkendale, Emilio de' Cavalieri 'Gentilhuomo Romano': His Life and Letters, His Role as Superintendent of All the Arts at the Medici Court and his Musical Compositions (Florence: Leo Olschki, 2001), pp. 85-120. 
musical composition of Euridice, ${ }^{18}$ but also by manoeuvring to be entrusted with the writing and production of the high point of the week-long festivities, Il Rapiamento di Cefalo. Although he oversaw the stage production of Euridice, Cavalieri saw little of his own music performed during the 1600 festivities. ${ }^{19}$ His gradual eviction (or, possibly, retirement) from the Medici court did not, however, prevent him from almost simultaneously triumphing on another stage. Indeed, his devotional oratorio Rappresentatione di Anima e di Corpo, performed a few months earlier in the Roman Oratory, was extremely well received, and the music of this innovative piece had already started to circulate in print by the time Euridice was staged in celebration of Maria's wedding. ${ }^{20}$

\subsection{The Accademia degli Alterati: From Counterculture to Court}

These rivalries among the musicians and patrons operating at Ferdinando's court are well known. But the role played by the Accademia degli Alterati in the conception of Euridice has hitherto received little attention, though the intellectual importance of the academy has long been recognised. The group was created in $1569 .{ }^{21}$ At first, their informal gatherings brought together only a handful of Florentine patricians. ${ }^{22}$ Many of these men belonged to lineages

18 As a result of this rivalry, Caccini chose his own singers for the first performance of Euridice and even rewrote some of Peri's music for them: see Palisca, 'The First Performance of Euridice', pp.11-13, 17-18. The competition between the two composers also resulted in the publication of a separate score for the work by Caccini, L'Euridice composta in musica in stile rappresentatiuo da Giulio Caccini detto Romano (Florence: Giorgio Marescotti, 16oo). This score was performed in the Pitti Palace on 2 December 1605.

19 It seems that Cavalieri restricted himself to composing music to accompany a dialogue in praise of the newlywed which was written by Giovanni Battista Guarini. The work was performed on the first evening of the festivities: see Palisca, 'The First Performance of Euridice', p. 2.

20 Cavalieri's work was published at the beginning of fall 1600: see Rappresentatione di Anima et di Corpo, nuovamente posta in musica dal Signor Emilio del Cavaliere, per recitar cantando, dato in luce da Alessandro Guidotti Bolognese (Rome: Niolò Mutii, 160o), reproduced in facsimile in 'Rappresentatione di Anima et di Corpo', reproduzione dell'unica edizione romana del 1600 a cura di Francesco Mantica, preceduta si un saggio di Domenico Alaleona (Rome: Casa Editrice Claudio Monteverdi, 1912). The book was originally dedicated to Cardinal Aldobrandino, and the dedication, signed by Guidotti, is dated 3 September 1600 .

21 The creators of the sodality appear to have been Giulio del Bene and Tommaso del Nero. For Giulio del Bene's rendering of the academy's origins, see his Historia del principio della Accademia, Biblioteca Apostolica Vaticana, Fondo Rossianio, 901, fols $1^{\mathrm{r}}-6^{\mathrm{v}}$. 
with a more or less pronounced anti-Medicean past. The coming to power of the Medici in 1537 had marginalised their families, who were left with diminished access to what remained of Florence's civic life. With little else to do but take care of their investments and tend to their villas-which they generally did diligently — their male offspring turned to intellectual activity. Yet, in doing so, they were not seeking to retire from public life. Rather, in search of reputation and prestige, they intended their academic activities to provide them with an alternate path to civic recognition, if not with targeted access to the Medici's entourage. As such, the academy was both the locus of an intellectual counter-culture and an institution designed to help its members find an acceptable place for themselves within the Medici court. ${ }^{23}$

This is no doubt why the group's institutional practices, as first set forth it its capitoli (statutes) made it the most secretive academy in Florence-in sharp contrast with the by-then mostly Medicean Accademia Fiorentina, whose public lessons were circulated widely in elegant books produced by Cosimo's official printer, Lorenzo Torrentino. ${ }^{24}$ The Alterati, on the other hand, far from publicising their gatherings, constantly attempted to hide their activities from everyone who was not part of the small circle of like-minded people they trusted. According to the academy's statutes, no forestiero (i.e., stranger to the academy) was allowed to attend its sessions; new members were only admitted with a unanimous vote of all academicians in their favour (and even those who were absent had to cast their vote in writing); and the circulation or publication of manuscript work produced in the academy without the explicit consent of the regent was strictly forbidden. ${ }^{25}$ This is not to say that the Alterati

23 For further analysis of the political positioning of the academy, see Déborah Blocker, 'Pro and anti-Medici? Political Ambivalence and Social Integration in the Accademia degli Alterati (Florence, 1569-ca. 1625)', in The Italian Academies 1525-1700: Networks of Culture, Innovation and Dissent, ed. by Jane Everson, Lisa Sampson, and Denis Reidy (New York: Routledge, 2016), pp. $3^{8-52 .}$

24 On the practices of the Humidi and the public and private lessons within the Accademia Fiorentina, see Plaisance, L'Accademia e il suo Principe, pp.113-16, 271-80, as well as Massimo Firpo, Gli Affreschi di Pontormo a San Lorenzo: eresia, politica e cultura nella Firenze di Cosimo I (Torino: Giulio Einaudi, 1997), pp. 155-290. The partially public meetings of la Fiorentina were circulated in print ex post via the printing of scores of academic orations in the workshop of Lorenzo Torrentino: see Antonio Ricci, 'Lorenzo Torrentino and the Cultural Programme of Cosimo I de' Medici', in The Cultural Politics of Duke Cosimo I de' Medici, ed. by Konrad Eisenbichler (Farnham: Ashgate Publishing Limited, 2001), pp. 103-20.

25 Biblioteca Nazionale Centrale di Firenze (hereafter BNCF), Magl. IX, 134, fols $8^{\mathrm{r}}, 9^{\mathrm{r}}, \mathbf{1}^{\mathrm{v}}$, and $15^{\mathrm{r}}$. The academy's atti (preserved as Biblioteca Medicea Laurenziana (hereafter BML) 
are to be viewed as active conspirators of any kind. Evidently, their institution could not have existed without tacit Medici approval. Yet it did not function as the regime's public academy - that is, as a carefully calibrated display of Florentine literary and philosophical talent—but rather as a private locus (accademia privata), in which it was possible to speak and write somewhat more freely, away from the tight constraints of ideologically-minded scrutiny. The Medici initially tolerated such a group because it was a way to keep a portion of the city's patrician elites occupied without giving it full access to the political positions that the ruling family reserved for those they trusted.

Among the Alterati, secrecy and nostalgic republicanism were mostly an ethos: the academy's procedures for keeping its activities private were real and, for the most part, effective, but on the whole the institution had little to hide, except for the fact that its members cultivated, both intellectually and in practice, a distant memory of the Florentine Republic, as well as non-conformist views on art, knowledge and politics. To a certain extent, these strategies of secrecy, associated with the cultivation of republican mores and values (such as equality, honesty, or humanism), were strategies of distinction, and can be viewed as a form of elitism in as much as they delineated not only a restricted form of intellectual sociability, but also the frontiers of a class (the Florentine patriciate). Yet these very practices did-albeit in a burlesque manner, at times - take loosely after the secretive manners of anti-Medicean activism, though such a reenactment was, by the last third of the 16th century, more folkloric than anything else.

The academy's daily occupations are a good example of how its members cultivated the memory of republican mores in practice. These activities, which only members could attend, centred on the production of judgments and the voicing of opinions, whether in prepared contradictory debates, in improvised confrontations or in the careful evaluation and editing of the productions of other members of the institution. Furthermore, they were carried out collectively, with the orator-often selected at random-having to convince his peers of the validity of his judgments or evaluations in elaborate academic orations. Thus, the ritualized academic exchanges of the Alterati were in many ways similar to the established practices of Florence's late oligarchical regime, in which pro et contra debates on policy issues, the drawing of speakers and officeholders through lots, and the public evaluation and censorship of policies (as well as of those that carried them out) were all central elements of the political culture. In the secluded space of the academy, the expounding

Ashb. 558.1 and 2) show that these rules were fairly strictly enforced: infractions were often sanctioned, for instance, if in a burlesque mode. 
of judgments and the voicing of evaluations on issues of art and learning prolonged, in the private sphere, the practices of public speech that characterised Florence's republican regime, transferring them to a newly established sphere of activity (aesthetics and, to a lesser extent, erudition) which — though certainly not without far-reaching political stakes—could, when needed, be passed off as politically innocuous.

The Alterati did not, however, only keep to themselves. They also engaged in activities that put them directly in contact with the Medici court, thereby using their academy not only as a place to interact among themselves, but also as a means to gain access to the political elites. In this respect, participating in the organisation of court festivities served the academy's contradictory goals extremely well, offering them an outlet for their erudition and creativity while also providing them with occasions to court the Medici. The academy was therefore frequently involved in preparing court festivities after the death of Francesco I in $1587^{26}$ - though, after the arrival of Cavalieri and the subsequent departure to Rome of two of its most central members, Giovan Battista Strozzi and Giovanni de' Bardi, the Alterati's influence on court spectacles dwindled. ${ }^{27}$ However, during the celebrations of 1600 , with Cavalieri's power in decline, many members of the academy were once again involved in the preparations. They were particularly active, in fact, in the creation of Euridice, and many of the aesthetic and ethical questions raised in the work can be traced back to their collective endeavours.

Ottavio Rinuccini was a recent member of the academy, in which his elder brother Alessandro (1555-1622) had been an active participant since 1573 . Ottavio was formally accepted in $1586 .{ }^{28}$ The academy's diary shows that the

26 Giovan Battista Strozzi and Giovanni de' Bardi were the two Alterati members who were most involved in such events. They worked in particular on the fourth intermedio of $L a$ Pellegrina: see Treadwell, Music and Wonder at the Medici Court, pp. 113-34.

27 Bardi was in Rome from 1592 to 1605 . Giovan Battista Strozzi left Florence in 1590 and seems to have returned in 1599 .

28 See the academy atti in BML Ashb. 558.1, fols $49^{\mathrm{v}}$ and $50^{\mathrm{r}}$, in which Alessandro Rinuccini is introduced into the academy, taking on the pseudonym l'Ardito, on 3 December 1573. Alessandro Rinuccini, who was, among other things, an accomplished scholar of both Latin and Greek, was subsequently elected three times to the regency of the Alterati, becoming the sixteenth, twenty-seventh, and forty-second regent. See BNCF Magl. IX, ${ }_{134}$, fol. $1^{v}$. He is also the author of a Latin poem on Saint Catherine, Diua Catharina martyr Alexandri Rinuccinii ad serenissimum Cosmum secundum magnum ducem Etruriae quartum (Florence: Cosimo Giunti, 1613). On l'Ardito, see Salvino Salvini, Fasti consolari dell'Accademia Fiorentina (Florence: Giovanni Gaetano Tartini, e Santi Franchi, 1717), pp. 326-29. Like several other Alterati members, Alessandro Rinuccini later occupied 
poet was in diligent attendance at its meetings in the late 1580 , throughout the 1590s, and in the early 1600 s. $^{29}$ Indeed, the posthumous edition of Rinuccini's Poesie, prepared in 1621 by his son Pier Francesco, clearly acknowledges his intellectual debt to the institution. ${ }^{30}$

administrative positions at court. He was depositario generale from 1612 to 1621 ; several hundred of the official letters he wrote while in this position are preserved in Archivio di Stato di Firenze (hereafter ASF), Miscelleanea Medicea 136 and 137.

29 Concerning Ottavio Rinuccini's early years in the academy (1587-1590), see BML Ashb. $55^{8.2}$, fols $60^{\mathrm{v}}, 65^{\mathrm{v}}, 73^{\mathrm{r}-\mathrm{v}}, 74^{\mathrm{r}}, 76^{\mathrm{r}-\mathrm{v}}, 78^{\mathrm{r}-\mathrm{v}}, 79^{\mathrm{v}}, 81^{\mathrm{r}}$, and $85^{\mathrm{r}}$. He was admitted at the age of twenty-four after being formally presented on 28 March 1586 . His formal introduction as a nuovo academico took place on 16 April 1587 . The statutes of the academy, including a list of its members (BNCF Magl., IX, 134, fol. $2^{r}$ ) reveal his pseudonym, which he seems to have determined only after several years as a member, as he appears earlier in the atti as 'Rinuccini'. Immediately preceding the staging of Euridice, Rinuccini was frequently present at Alterati meetings, now under the name of il Sonnachioso (вмL Ashb. $55^{8.2}$, fols $102^{\mathrm{v}}, 103^{\mathrm{v}}, 105^{\mathrm{r}-\mathrm{v}}, 108^{\mathrm{r}}$ ). His last recorded appearance at a meeting during that second period was during the General Council of 3 August 160o, two months before the performance of Euridice. After Maria's wedding, Rinuccini followed the new queen to France, but a few years later, shortly after his return to Florence, at the General Council held on 31 August 1603, il Sonnachioso is once again listed as present (BML Ashb. 558.2, fol. $121^{\mathrm{r}}$ ). He is last mentioned in the atti (which have been preserved only through early 1606) on 20 December 1604, in attendance at a lesson on the subjects appropriate to tragedy and epics according to Aristotle's Poetics (BML Ashb. 558.2, fol. 127 v). On Rinuccini among the Alterati, see also the notations in Palisca, 'The Alterati of Florence', p. 15, and Gary A. Tomlinson, 'Ottavio Rinuccini and the Favola Affettuosa', Comitatus: A Journal of Medieval and Renaissance Studies, 6 (1975), pp. 2-27 (p. 3). Several codices containing poems by Ottavio Rinuccini, including some in his hand, are preserved in BNCF Palat. 249, 250, and 251; BNCF Magl. VII, 562 and 563 (now listed as BNCF Fondo Nazionale II.IV.17); and BNCF Magl. VII, 907.

30 Ottavio Rinuccini, Poesie alla Maestà Cristianissima di Luigi XIII, Re di Francia, e di Navarra (Florence: Giunti, 1622), "Ai Signori Accademici Alterati," no pagination. The Alterati's statutes required that texts produced within the academy by one of its members be published only with the approval of the institution. Accordingly, in the opening pages of this luxurious volume of poems (which contained a reprinting of Euridice), Pier Francesco published a letter in which he claimed that if he had not formally requested a formal authorisation to publish his father's complete extant poems, it was only because he felt that the poet's great talents allowed him to dispense with it. By alluding to this rule and by expressing the hope that, at the sight of the volume, the academy would approve retrospectively of his efforts, Pier Francesco was indirectly acknowledging that many of his father's most celebrated works, including Euridice, were produced in connection with debates having taken place among the Alterati. Given that the academy was by then clearly in decline, this public acknowledgment is all the more striking. 
Corsi also had ties to the Alterati. Like many other Florentine patricians, he actively courted the academy and is mentioned at least twice in its records as a forestiero (visitor) whose name was put up for a vote. ${ }^{31}$ Corsi, apparently, was never formally admitted, ${ }^{32}$ but he did sporadically attend meetings even after his two failed election processes, including one in the months immediately leading up to the production of Euridice. ${ }^{33}$ His eldest son Giovanni Corsi (1600-1661) was, however, admitted into the institution after 1606. ${ }^{34}$

Like Corsi, the musician and singer Peri was never a member of the Alterati, possibly because he was not considered sufficiently learned to gain entry, but many of the other individuals associated with the wedding celebrations were, such as Giovanni de' Medici (1567-1621), who supervised the decorations as well as the intermedi and staging of Il Rapiamento di Cefalo. ${ }^{35}$ Michelangelo Buonarroti, who wrote the official relazione (narrative) of the celebrations, was a regular visitor to the academy, though he too does not seem to ever have been a full member. ${ }^{36}$

BML Ashb. 558.2, fols $65^{\mathrm{v}}$ (Corsi and Rinuccini were candidates together, but only Rinuccini appears to have been fully admitted) and $105^{\mathrm{v}}$.

It is possible that Corsi never obtained the unanimous vote that was required, either because he was not enough of a scholar to convince some of the academy's letterati or because, at the time of his candidacies, his links to the Medici were too strong for the taste of at least one member. It is also possible that Corsi himself did not wish to become a full member-which would have demanded an important commitment of time and effort-but preferred instead to remain an unofficial sympathizer.

33 For instance, on 31 January 1599 (1600), nine months before the staging of Euridice, Corsi heard a lesson on Virgil's Aeneid: see BML Ashb. 558.2, fol. $105^{\mathrm{r}}$.

34 BNCF Magl. IX, 134, fol. $3^{v}$. This election likely took place between 1615 and 1620, when the academy was dwindling and eager to admit young and promising new members. No records are extant after January 1606.

35 Giovanni de' Medici, in particular, was responsible for the giardino (garden) and the giglio (buffet in the shape of the Florentine fleur-de-lis). He also designed the decorations for the banquet during which a dialogue by Giovan Battista Guarini was performed. See Kirkendale, Emilio de' Cavalieri, pp. 368 and 372, as well as Palisca, 'The First Performance of Euridice', pp. 2-3. Giovanni was inducted into the academy in February 1587 and was frequently present thereafter: see BML Ashb. $55^{8.2}$, fols $68^{\mathrm{r}-\mathrm{v}}, 7 \mathrm{0}^{\mathrm{r}}, 71^{\mathrm{v}}, 73^{\mathrm{r}}, 101^{\mathrm{r}-\mathrm{v}}$, and $102^{\mathrm{v}}$. He was particularly close to Giovan Battista Strozzi, who helped him gain admittance into the academy.

36 See вмL Ashb. 558.2, fols $103^{\mathrm{r}}, 105^{\mathrm{r}}$, and $129^{\mathrm{v}}$. Full members were those who had been elected in due process (i.e., within the Alterati, unanimously). Buonarroti never reached that point, according to the atti. But he was frequently marked as present as a forestiero (visitor to the academy). 


\subsection{Pleasure, Utility and the Poetics of Aristotle}

Obviously, some of these men participated much more closely in the intellectual labours of the academy than others. Yet since both secrecy and collective discussions were central to the institution's ethos it is sometimes difficult to determine which members were particularly involved in a given debate. ${ }^{37}$ We do, however, know with certainty that, throughout the life of the academy, Aristotle's Poetics was intensely discussed among its members, who most often approached the original via Piero Vettori's (1499-1585) translation and commentary. ${ }^{38}$ Indeed, the Alterati's reading of the Poetics adopted several of the key interpretations proposed by this Florentine scholar. Like Vettori, many Alterati stressed that, according to Aristotle, the main goal of tragedy and music should be pleasure, though moral utility was not to be excluded. ${ }^{39}$ In particular, they refused to subordinate pleasure to utility, which would have

37 For an in-depth analysis of the academy's collective activities, see Déborah Blocker, 'S'affirmer par le secret: anonymat collectif, institutionnalisation et contre-culture au sein de l'académie des Alterati (Florence, 1569-ca. 1625)', Littératures classiques, 80 (2013), pp. 167-90.

38 See Weinberg, 'The Accademia degli Alterati and Literary Taste' and 'Argomenti di discussione letteraria nell'Accademia degli Alterati'. Vettori's translation of and commentary on the Poetics was published twice: Petri Victorii Commentarii in primum librum Aristotelis de Arte poetarum [...] (Florence: Giunti, 1560 and 1573). While in Pisa in 1573, Giovan Battista Strozzi and Filippo Sassetti annotated together a manuscript copy of Vettori's Latin translation of the Poetics, currently preserved as BNCF Magl. VII, 1199 with the added title: Aristotelis Poetica cum notis Petro Victorio Interprete. Over the years, other academicians entered their own annotations into this manuscript, turning it into a reference book for their collective internal discussions on the Poetics. Finally, in 1617, Strozzi had this manuscript printed by the Giunti without the annotations, with the aim of furnishing younger academicians with a study tool that they could use to work on the glosses penned into BNCF Magl. VII, 1199. The only surviving copy of this limited edition is currently preserved at the BNCF under the title Aristotelis Poetica Petro Victorio Interprete (BNCF Magl. 5.9.119). In the Biblioteca Riccardiana (hereafter вR), an unfinished vernacular commentary on the Poetics in Sassetti's hand can also be found (BR 1539 , fols $80^{r}-126^{v}$ ). It is similarly indebted to Vettori. Finally, the Biblioteca Nazionale Centrale di Firenze holds a copy of Vettori's edition of the Poetics in Greek, Aristotelous Peri poiētikēs. Aristotelis De arte poetica. Ad exemplar libri à Petro Victorio correcti (Florence: Giunti, 1564), with extensive annotations that were probably penned in by a hitherto unidentified member of the academy (BNCF Postillati 39). On the academy's annotations and commentaries on the Poetics, see Déborah Blocker, 'Le lettré, ses pistole et l'académie: comment faire témoigner les lettres de Filippo Sassetti, accademico Alterato (Florence et Pise, 1570-1578)?', Littératures classiques, 71 (2010), pp. 31-66 (in particular pp. 57-62).

39 On Vettori's hedonistic poetics, see Donatella Restani, 'Girolamo Mei et l'héritage de la dramaturgie antique dans la culture musicale de la seconde moitié du XVIe siècle', in $L a$ 
been the norm in Florence at the time of Cosimo I. ${ }^{40}$ Instead, they claimed that poetry's most central moral benefits stemmed precisely from the very pleasure it provoked.

For instance, a manuscript transcription of Vettori's Latin translation of the Poetics (currently preserved as BNCF Magl. VII, 1197), which was collectively annotated over forty years by at least half a dozen Alterati members, discusses Aristotle's claim that in order for tragic poems to produce the pleasure that is specific to them, they must be composed of a single, whole, and complete action (1459a 15-20). On folio $74^{\mathrm{r}}$, one of the annotators, Filippo Sassetti (1540-1588), who was officially admitted to the Alterati in early February 1574, rephrases this assertion in a way that indicates he is interested in stressing the importance of action in the creation of tragic pleasure, and wants to distinguish this pleasure from issues of morality. To this aim, Sassetti underlines that the pleasure arising from what Aristotle declares to be the appropriate type of tragic action is the pleasure of the play's own beauty, not that which arises from the purgation of the passions. ${ }^{41}$ This is a telling interpretation because, since the mid-sixteenth century, the clause in which Aristotle defines tragedy as an action that provokes a type of catharsis (1449b 23-29) had played a central role in readings of the Poetics that attempted to restrict tragedy's goals to a moral aim, with the notion of 'purgation of the passions' mostly being the result of the interpretations, translations, and commentaries that this interpolated passage gave rise to. ${ }^{42}$ In contrast, by stressing the importance of action and the specific beauty it generates, Sassetti appears to be much more interested in defining a poetics of tragedy that is based centrally on pleasure.

Naissance de l'opéra, ed. by Decroisette, Graziani, and Heuillon, pp. 57-96 (in particular pp. 76-94).

40 See Déborah Blocker, 'Dire l'“art” à Florence sous Cosme I de Médicis: une Poétique d'Aristote au service du Prince', AISTHE, 2.2 (2008), pp. 56-101.

41 BNCF Magl. VII, 1199 (added title: Aristotelis Poetica cum notis Petro Victorio Interprete), fol. $74^{\mathrm{v}}$ (annotation in Sassetti's hand): 'Mostra [Aristotile] perchè conto l'attione per esser bella debba havere l'unità con l'esempio delle cose naturali belle, le quali hanno unità e integrità le quali dua cose fanno la bellezza dalla quale nasce il piacere però è da avvertire che egli [Aristotile] intende qui il piacere della sua propria bellezza e non quello che nasce dalla purgatione. Se uno dirà che all'historia ancora fa di mestiere questa bellezza, gli risponderemo esser vero che ell' è una e intera ma non ricerca la bellezza della poesia che consiste in'imitare una verità.'

42 On the place of catharis in Aristotle's text, see Claudio Veloso, 'Aristotle's Poetics without Katharsis, Fear, or Pity', Oxford Studies in Ancient Philosophy, 33 (2007), pp. 255-84. On Renaissance reworkings of this obscure clause, see Blair Hoxby, What Was Tragedy? Theory and the Early Modern Canon (Oxford: Oxford University Press, 2015), p. 62. 
In a similar way, the Alterati held in high regard the Aristotelian notion of meraviglia (wonder) as well as the stupore (astonishment) it produces, emphasising that both were key to poetry because they work to create pleasure in the spectator. Even while giving great importance to the seductions of meraviglia, however, the Alterati did not exclude the possibility of moral utility emerging from the workings of stupore. From this point of view, some of the notations on fols $82^{\mathrm{v}}$ to $84^{\mathrm{r}}$ of their annotated manuscript of Vettori's translation of the Poetics are revealing. They show how Sassetti and another annotator, probably his cousin Lorenzo Giacomini $\left(155^{2-1598)}\right)^{43}$ work to distinguish poetical goals from political ones, while also underscoring that meraviglia can serve moral ends. Sassetti begins by stressing that, according to Aristotle, poetry and politics concur in that they both aim at making the body politic happy. In response, Giacomini focuses on the importance of pleasure, insisting that tragic poetry must primarily delight its audience by means of the unexpected events it stages. In the conclusion of this exchange, Giacomini adds a note to a remark previously penned in by Sassetti. In this note, he designates wonder (meraviglia) as tragedy's main goal precisely because, in delighting the spectators, it generates good habits in them ('la maraviglia è il fine della Poesia, e questa per poter in altrui generar buon costumi'). He also stresses that 'it is not unbefitting that one end [pleasure] concurs with the other [utility]' ('non è inconveniente che un fine riguardi l'altro'), thus agreeing in fine with Sassetti. ${ }^{44}$

43 Lorenzo Giacomini officially became a member of the Alterati in 1583 , but had been active within the group since the early 1570 . His hand seems to be present in BNCF Magl. VII, 1199, fols $74^{\mathrm{v}}, 75^{\mathrm{r}}, 77^{\mathrm{r}-\mathrm{v}}, 79^{\mathrm{r}}, 80^{\mathrm{r}}, 83^{\mathrm{r}}, 84^{\mathrm{r}}, 85^{\mathrm{v}}, 86^{\mathrm{r}}, 86^{\mathrm{v}}, 92^{\mathrm{v}}$. These occurrences can be compared with a copy of Annibal Caro's Italian translation of Aristotle's Ethics (Venice: Al segno della Salamandra, 1570), which Giacomini annotated extensively and signed with his monogram on the title page of the first volume (Biblioteca Universitaria di Pisa, Mss $55^{1}$ and $55^{2}$ ). I am most grateful to Anna Siekiera for having brought these volumes to my attention.

The dialogue unfolds on several fols of BNCF Magl. vII, 1199. On fol. 82 $2^{\mathrm{v}}$, Sassetti stresses the articulation of poetics and politics: 'Hora è da sapere che di quelle due poesie in fino sono duoi, un prossimo, et uno ultimo, il prossimo eccita misericordia e terrore, l'ultimo il purgare. I mezzi loro sono le cose terribili e compassionevoli. Hora la rettitudine dell'arte poetica consiste nel conseguire questo fine mediante questi mezzi. Aristotile fece mentione dell'arte Politica perche ella concorre con la Poetica: [in ?] trattare attioni humane per il suo fine è il fare tutta la citta felice et i suoi mezzi sono le buone leggi però la sua rettitudine consisterà in conseguire questo fine mediante questi mezzi.' On fol. $83^{\mathrm{r}}$, in contrast, Giacomni insists on pleasure and surprise: 'Ma la dirittura della Poetica consiste in rassomigliar con parole harmonizzate una attione humana possibile ad avvenire, dillettevole per la novità delle accidente.' On fol. $84^{\mathrm{r}}$, however, both men write a joint annotation (of the underlined Latin text) and seem to compromise: '[Sassetti] Si quæ adversus, 
Because the Alterati carefully cultivated dissension rather than consensus, these positions cannot be attributed to the entire academy without qualification. Nevertheless, it is fair to say that pleasure in a variety of guises (not just aesthetic pleasure) was generally conceived as conducive to moral betterment by many of the most active Alterati. ${ }^{45}$

The Alterati's fascination with diletto (delight) and stupore (astonishment) in spectacle is also evident in many of the creative texts they authored (dialogues, poems, and even orations), where they are frequently associated with cognitive or moral benefits. Most of the Alterati's writings had a very limited audience because, like their annotated manuscript of Vettori's Latin translation of the Poetics (BNCF Magl. VII, 1199), many remained in manuscript and circulated only among members and associates of the academy. With Euridice, however, the Alterati's positions on theatre, music, and the pleasures to be derived from them came to life for the first time in a fully-fledged spectacle-one that was widely publicized and heavily legitimized by its inclusion in the weeklong celebrations of Maria and Henry's wedding. Via the courtly performance and by way of separate printed editions of the musical score as well as the libretto, the opera reached an audience that none of the Alterati's other productions had ever had before. ${ }^{46}$ In this respect, Euridice offered the academy an exceptional opportunity, allowing it to showcase and disseminate its points of view on poetry, love, and pleasure without the need to divulge its identity as an institution or the obligation to publish widely the theoretical debates it had spent quite a bite of energy keeping private for decades. With the creation and performance of Euridice, the contours of a new kind of dramatic experience were defined and even exemplified, one in which the pleasures available in the material world (those of art, but also those of love) were extolled,

ipsam artem: qui coniunge l'impossible e'l peccar in un arte e dice cosi se il poeta fa cose impossibili e pecca ancora in qualche arte egli ha peccato, ma non dimeno hà fatto bene perche $\left[\mathrm{e}^{\prime}\right]$ l'ha fatto per conseguire il suo fine e se bene hà tolto mezzi non buoni e da salvarlo perchè cosi l'ha conseguito maggiormente. [Giacomini] Il M[aggi] pon per fine della Poesia homines virtutibus exornare, ma non è inconveniente che un fine riguardi l'altro, comme nella medicina, la sanità è il fine, e questo per potere operare, così la maraviglia è il fine della Poesia, e questa per poter in altrui generar buon costumi.'

45 I am thinking in particular of Strozzi, Sassetti, Rinuccini, and Giacomini.

46 Le Musiche di Jacopo Peri, nobil fiorentino, sopra L'Euridice, del Signor Ottavio Rinuccini, rappresentate nello Sponsalizio della Christianissima Maria Medici Regina di Francia e di Navarra (Florence: Giorgio Marescotti, 16oo). Rinuccini's text was printed in a standalone edition in 1600 as L'Euridice d'Ottavio Rinuccini rappresentata nello sponsalitio della christianissima regina di Francia, e di Nauarra (Florence: Cosimo Giunti, 160o), and was subsequently reprinted in the sumptuous edition of his Poesie in 1622. 
while at the same time their moral value was underscored. As befit a spectacle that constantly reflected upon the relationship of the material to the spiritual, the experiment of creating this new theatrical genre included an elaborate questioning of the group's understanding of the relationship of art to political power, by way of an allegorical representation of the Alterati's current (and very concrete) positioning at court.

2

\section{The Spiritual Spectacle of Love and Art: From Pleasure to Transcendence in Euridice}

Euridice's formal novelty is frequently characterised, among historians of music, as residing in its attempt to blend poetry, music, and dance into a spectacle that remained dramatic at its core-inasmuch as it represented an action inspired by a myth. The major difference between Euridice and a court play was that the former's dialogues were sung instead of declaimed, with the occasional intervention of choruses and/or dancers. Of course, this type of spectacle (one that brought together theatre, music, chants, and dance) was not new in itself, nor did its inventors ever claim that it was, insisting rather that their work was inspired by the mixture of declamation, music, and dance that they (and many other Italian humanists) believed had originally characterised classical Greek drama. ${ }^{47}$ But, at the court of Florence Euridice represented a novelty with respect to the intermedi that had been developed under Medici rule-as divertimenti to be performed during the intermissions of a court drama-because it associated poetry, music, and dance to produce a more dynamic, developed and complete type of dramatic action than the lavish tableaux that had become customary during these intervals.

Yet Euridice, despite its innovations, shared one central characteristic with most early modern court performances, including the Florentine intermedi

47 Le Musiche di Jacopo Peri, nobil fiorentino, sopra L'Euridice, 'Ai Lettori': 'Onde veduto, che si trattava di poesie Dramatica, e che però si doveva col canto chi parla (e senza dubbio non si parlò mai cantando) stimai, che gli antichi Grei, e Romani (i quali secondo l'openione di molti cantavano su le Scene le Tragedie intere) usassero un' armonia, che avanzando quella del parlare ordinario, scendesse tanto della melodia del cantare, che pigliasse forma di cosa mezzana' (for a translation, see Jacopo Peri, Euridice: An Opera in One Act, Five Scenes, Libretto by Ottavio Rinuccini, ed. by Howard Mayer Brown (Madison: A-R Editions, 1981), 'To my readers', plate II). On the rediscovery of classical tragedy by Renaissance humanists, see, for instance, Maria Cecilia Angioni, 'L'Orestea nell' edizione di Robortello da Udine (1552)', Lexis, 28 (2010), pp. 465-78. 
and the English court masques: it was designed to be enjoyed and deciphered as a multi-layered allegorical spectacle. ${ }^{48}$ As such, it pointed in two different but complementary directions. On the one hand, it invited spectators to understand its plot in relation to the immediate social and political circumstances in which the drama was being represented. But it also simultaneously aimed at directing the spectator's attention to higher truths, be they aesthetic, moral, or spiritual. These types of spectacles embodied multiple significations at once, even managing at times to use one level of allegorical meaning to reinforce or deepen the other. This sometimes restricted the understanding of the performance to a handful of insiders, but it did offer the benefit of allowing the spectacle to become a vehicle for complex equivocal insinuations-thereby facilitating, when needed, the discreet voicing of non-conformist points of view. ${ }^{49}$

Euridice's plot is loosely based on the myth of Orpheus, as told in Ovid's Metamorphoses (x. 1-85). The sources mediating between the Ovidian text and Rinuccini's plot are of course numerous and complex, as is often the case with early modern operatic adaptations of Ovid ${ }^{50}$ - though, in the case of Rinuccini's libretto, Angelo Poliziano's Fabula d'Orfeo (1478-1483?) was clearly an important locus of inspiration. ${ }^{51}$ Yet, while Poliziano respected the Ovidian outcome-in which Orpheus loses Eurydice for the second time as he is leading her out of Inferno-Rinuccini's libretto departs from this well-established tradition and provocatively reverses the ending from tragic to happy, opening the way for other operatic reconfigurations of the myth in which Orfeo and Euridice are blissfully reunited at the end. ${ }^{52}$ Euridice consists of a prologue followed by five scenes, during which the action leads from a joyous beginning (the celebrations of Orfeo and Euridice's wedding) to a sorrowful event

48 For a general overview of allegorical drama in the Renaissance, see Blair Hoxby, 'Allegorical drama', in The Cambridge Companion to Allegory, ed. by Rita Copeland and Peter T. Struck (Cambridge: Cambridge University Press), pp. 191-210.

49 I have investigated the two-fold allegorical nature of early modern court performances in greater depth in a prior study: Déborah Blocker, Instituer un 'art': politiques du théâtre dans la France du premier XVII e siècle (Paris: Champion, 2009), pp. 185-203.

5o On these mediations, see Wendy Heller's forthcoming study, Animating Ovid: Opera and the Metamorphoses of Antiquity in Early Modern Italy.

51 Angelo Poliziano, Stance / Stanze et Fable d'Orphée / Fabula di Orfeo, introd. and trans. by Émilie Séris, texts and notes by Francesco Bausi (Paris: Les Belles Lettres, 2006).

$5^{2}$ On these subsequent works, see Jeffrey Buller, 'Looking Backwards: Baroque Opera and the Ending of the Orpheus Myth', International Journal of the Classical Tradition, 1.3 (1995), pp. $57-79$. 
(Euridice's sudden accidental death), and ends in a final reversal in tone and mood (after Orfeo manages to convince Pluto to let him take Euridice back to the world of the living). The last scene of the opera stages the miraculous reappearance of Euridice on earth, followed by Orfeo's triumph, in the presence of the whole cast. In keeping with the long tradition of the moralisation of Ovid's tales, the signification of this action is however far more complex than this brief summary can suggest, for, in Rinuccini's libretto, the plot primarily serves to investigate the dual nature of art, in the enjoyment of which sensual pleasure is shown to lead to a form of spiritual enlightenment.

\subsection{Suggesting a Continuity Between Sensual Pleasure and Spiritual Bliss}

Euridice famously opens with a prologue in which a personification of tragedy announces, with majesty and poise, that she no longer intends to spin tales of bloodshed and tyranny with the aim of arousing pity or fear. Rather, displaying 'changed forms' ('cangiate forme') in honour of the joyful occasion provided by the royal wedding, Tragedy promises to generate 'astonishment' ('stupore') and 'sweet delight' ('dolce diletto'). ${ }^{53}$ While Rinuccini and Peri's intention to create a lieto fine (happy ending) has been much commented upon, their affirmation of their desire to create both wonder and pleasure has received far less attention. Yet this last assertion embodies most of the aesthetic and moral goals of the work, tying their project to the notion of meraviglia and, more generally, to that of moral and spiritual enjoyment. For sensual pleasure-via the creation of musical harmony, as much as through the production of a sumptuous spectacle-is constantly associated in the opera with the idea of moral betterment, and even with the spiritual elevation of the 'noble heart' ('nobile cor').54

In fact, from the opening scene onward, sensual and spiritual pleasure are depicted as so closely intertwined that they appear to be almost indistinguishable. This first scene displays a pastoral spectacle of joy and happiness, in celebration of Orfeo and Euridice's wedding: shepherds and nymphs express their 'joy' ('gioia') and 'delight' ('diletto'), while Euridice voices her 'pleasures' ('i miei diletti'). But, during the celebration, the chorus sings and dances to celebrate this 'blessed day' ('beato giorno'), an expression that begins to suggest to the spectator or reader that a correlation between sensual pleasures and spiritual ones is being elaborated. ${ }^{55}$ Simultaneously, the association of material and immaterial joys, as generated by the spectacle of the lovers' happiness,

53 Jacopo Peri, Euridice, prologue, p. xvi.

54 Ibid., scene 1, p. xvi.

55 Ibid., scene 1, pp. xvii-xix. 
is underscored by a chorus nymph, who stresses that only an 'ignoble heart' ('rozzo core') would not 'be filled with delight and sweetness' at the sight of the 'rare fortune of such a beautiful love' ('Che di si bell'amor l'alta ventura | Non colmi di diletto e di dolcezza?'). ${ }^{56}$ The love that Orfeo and Euridice share thus becomes not only a symbol of a form of spiritual sensuality, but also the emblem of an aristocratic ethos in which pleasure, beauty, and ethics are tightly intertwined. This ethos was in many ways similar to that of the Alterati, who, as a patrician academy, strove to enact and perpetuate-via the production and appreciation of art-an ideal form of nobiltà. ${ }^{57}$

Scene 2 makes these allegorical associations between sensual pleasure and celestial bliss even clearer. It starts with Orfeo's own song of joy, performed as he impatiently awaits his wedding night, anticipating the pleasures soon to come. In his response, Tirsi, a shepherd, stresses that this newly found amorous happiness is in fact as much a spiritual joy as a sensuous one, since the lovers will share angelic beatitude, wearing on their faces a 'smile from Heaven' ('un riso di Paradiso'). ${ }^{58}$ Though this image may seem to borrow mainly from Ficino's neo-Platonic conceptions of love, the spiritual connotation is counterbalanced by Orfeo's voicing of his fiamme ('flames') and ardori ('desires') in the same scene - that is, by the explicit expression of his carnal desire for Euridice. ${ }^{59}$ While certainly commonplace in early modern Italian love poetry, these words of sexual desire and emotional upheaval probably also evoke another tradition of Renaissance discourses on pleasure, namely the one initiated by Agostino Nifo's De amore et pulchro liber (1531). In this text, the Campanian philosopher stresses the legitimacy of sensual pleasure, whether in the appreciation of love, beauty, or art. ${ }^{60}$ His work circulated throughout sixteenth-century Italian court culture and was, for instance, well known to Torquato Tasso, who stages Nifo as the central interlocutor of his dialogue Il Nifo ovvero del Piacere (The Nifo, or on

$56 \quad$ Ibid., scene 1, p. xvii.

57 A similar ideal was simultaneously being defined across much of the Florentine patriciate: see, for instance, Paolo Mini, Discorso della nobiltà di Firenze e dei Fiorentini (Florence: Domenico Manzani, 1593).

$5^{8}$ Jacopo Peri, Euridice, scene 2, p. xx.

59 Ibid., scene 2, p. xix. Carter, 'Epyllia and Epithalamia', stresses that explicit expressions of carnal desire are habitual in courtly wedding entertainments. However, the constant association of sexual arousal and spiritual bliss seems to be a specificity of this particular divertimento.

6o See Agostino Nifo, De Pulcro et amore I-De Pulchro Liber. Du Beau et de l'amour ILe Livre du Beau, ed. and trans. by Laurence Boulègue, 2 vols (Paris: Les Belles Lettres, 2003-2011). 
Pleasure, c. 1580). ${ }^{61}$ Several central Alterati members, including Rinuccini, were close to Torquato Tasso both personally and intellectually during the last two decades of his life. ${ }^{62}$ There is therefore little doubt that, either directly or via Tasso, many of them had come into contact with the writings of Nifo.

In scene 2 of Euridice, however, Tirsi's serene evocation of the pleasures of love, in which sensuality and spirituality appear united, is short lived. He is immediately interrupted by the arrival of Dafne, who declares her heart to be full of 'pity' ('pietate') and 'terror' ('spavento'), and the musical mode changes from joyful to lugubrious, marking the first reversal in the action. Dafne goes on to recount pitifully the death of Euridice. Her narrative is particularly interesting because a number of its details depart from the Ovidian myth, thus allowing us to better understand the ways in which Rinuccini tweaks the original tale in order to serve the elucidation of his views on the dual nature of the pleasures of both love and art. Dafne explains that Euridice was taking 'sweet delight' ('dolce diletto') in the proximity of a stream, singing and dancing to her own songs, when a snake bit her. ${ }^{63}$ Ovid, in contrast, does not mention that Euridice was singing or dancing when the viper struck her. These added details are telling because they allegorically associate the character of Euridice with music and dance, two activities often described in the Renaissance as sensual and therefore impious. ${ }^{64}$ In Rinuccini's libretto, it is precisely while engaging in these worldly pastimes that Euridice is mortally struck, as if to remind the spectator of such accusations. These accusations will, however, be refuted in the finale, when Orfeo celebrates his victory over death thanks to the power of both music and love, in a display of joyful melodies and dances involving the whole cast. ${ }^{65}$ Meanwhile, however, upon learning of Euridice's death in

61 Torquato Tasso, Dialoghi, ed. by Giovanni Baffetti, 2 vols (Milano: Rizzoli, 1998), I, pp. $230-303$.

62 The Alterati protected Tasso while he was in Florence during the late 1580 os and early 1590s, and staunchly defended his work after his death, most notably in a funeral oration delivered by Giacomini to the academy and published in 1595 with its approval. See Lorenzo Giacomini, Oratione in lode di Torquato Tasso fatta ne l'Academia degli Alterati da Lorenzo Giacomini Tebalducci Malespini (Florence: Giorgio Marescotti, 1595; second edition in 1596).

63 Jacopo Peri, Euridice, scene 2, p. xxii.

64 On these issues, see Alessandro Arcangeli, David o Salomè? Il dibattito europeo sulla danza nella prima étà moderna (Treviso: Fondazione Benetton Studi Ricerche, 200o); Recreation in the Renaissance: Attitudes towards Leisure and Pastimes in European Culture, c. 1425-1675 (New York: Palgrave Macmillan, 2003); and Passatempi rinascimentali: storio culturale del divertimento in Europa, secoli $X V-X V I I$ (Rome: Carocci, 2004).

65 Jacopo Peri, Euridice, scene 5, p. xxxvii. 
scene 2, Orfeo laments the transient nature of all earthly pleasures and exits vowing to join his beloved in death.

A second reversal begins to take shape immediately thereafter, however, with the recounting of a mysterious apparition in scene 3. Orfeo's companion, Arcetro, tells of his friend's despair in discovering Euridice's lifeless body and of the subsequent descent from the heavens of a lady of celestial appearance' ('donna viddi celeste'), who offers the disconsolate lover her 'heavenly help' ('celestio soccorso'). ${ }^{66}$ This figure, who makes her stage entry in the next scene, is identified in the cast as Venus, but her identity remains mysterious throughout Arcetro's narrative. When Orfeo refers to her as '(bella) madre d'Amore' ('beautiful mother of Love'), ${ }^{67}$ the primary image evoked is that of the Virgin Mary, a figure of attention, care, and generosity who embodies the highest forms of human love. For this reason, Charitas (Charity) also comes to mind, especially since this mysterious allegorical figure holds out her hand to Orfeo and vows to assist him in his quest to retrieve Euridice from the underworld. Because the figure of Orpheus had been associated with that of Christ throughout the Middle Ages, ${ }^{68}$ these Christian readings would have been particularly obvious to a sixteenth-century Florentine audience. Thanks to this complex set of allegorical superimpositions, the pagan and sensuous image of Venus assisting a lover opened, in Euridice, onto that of the Virgin Mary lovingly assisting a Christlike figure in his terrestrial woes and in his ascension, through the resurrection of his lover, to the status of a pagan demigod. These associations further suggested that amorous pleasures and, more generally, all material ones, can have spiritual value and should be understood (and appreciated) as capable of leading to the beatific apprehension of transcendent truths. This would of course be true of music itself, the spiritual power of which Rinuccini's libretto also underscores quite clearly. Indeed, the figure of Venus/Mary/Charitas is also indirectly associated, in Euridice, with artistic creation and, more specifically, with music. For, it is Venus who invites Orfeo to go to Inferno 'to display [his] noble song to the sound of [his] gilded lyre' ('Sciogl'il tuo nobil canto $\mid \mathrm{Al}$ suon dell'aureo legno'). ${ }^{69}$ As the figure of Orfeo goes from bereavement and grief to a quasi-apotheosis in the company of his resurrected beloved, thanks to the transcendent power of his lyre, the carnal

\footnotetext{
66 Ibid., scene 3, p. xxvi.

67 Ibid., scene 2, p. xix, and scene 4, p. xxviii.

68 On this tradition, see John Block Friedman, Orpheus in the Middle Ages (Cambridge: Harvard University Press, 1970).

69 Jacopo Peri, Euridice, scene 4, p. xxviii.
} 
pleasure of music is allegorically depicted as leading to spiritual bliss through the arousal of our emotions and senses.

\subsection{Euridice: $A$ Material Incarnation of Transcendence}

The continuity postulated, in Euridice, between the material world and the immaterial one is, however, most clearly depicted in the figure of Euridice herself. This is particularly evident in the last scene of the opera, which recounts Euridice's return to earth. Only a handful of Peri's and Rinuccini's courtly spectators would have been unaware that this outcome was entirely contrary to Ovid's. ${ }^{70}$ In contradicting Ovid's tale, Rinuccini was also going against the grain of the allegorical readings of Metamorphoses that had been produced during the late classical period, most notably by Boethius. Indeed, in the Consolation of Philosophy, Orpheus is said to lose his access to the spiritual world (represented by daylight) when he indulges in his carnal desire for Euridice and turns his head back towards the Inferno in order to catch a glimpse of her. ${ }^{71} \mathrm{By}$ transforming this famously tragic episode into a happy ending, Rinuccini is suggesting a morality that directly contradicts Boethius's allegorical reading. In showing how Euridice is brought back to life thanks to the pleasures of music and dance, the Florentine poet is indirectly asserting that a form of spiritual satisfaction can - and in fact should - be found on earth, among the carnal pleasures of love and art. This is undoubtedly why, in Rinuccini's libretto, what initially kills Euridice (her enamoured chanting and dancing in the vicinity of a stream, during which she is bitten by a snake) is also what brings her back to life (thanks to the enamoured chanting of her lover).

The entire dénouement of the opera-from the resuscitation of Euridice, which makes her beautiful body seem like a divine apparition, to the elevation of the Apollonic figure of Orfeo to the status of a 'demigod' 72 — seems designed to illustrate and embody a continuity between the enjoyment of sensual pleas-

70 Rinuccini acknowledges this fact in the dedication to Maria that he placed at the beginning of the 1600 edition of his poem: 'Potrà parere ad alcuno che troppo ardire sia stato il mio in alterare il fine della favola d'Orfeo, ma così mi è parso convenevole in tempo di tanta allegrezza, havendo per mia giustificatione esempio di Poeti Greci, in altre favole, \& il nostro Dante ardi di affermare essersi sommerso Ulisse nella sua naviguatione, tutto che Omero, e gli altri Poeti havessero cantata il contrario. Così parimente ho seguito l'autorità di Sofocle nell'Aiace in far rivolger la Scena non potendosi rappresentar altrimenti le preghiere, \& i lamenti d'Orfeo.' For a full translation of this dedication, see Oliver Strunk, Source Readings in Music History: The Baroque Era (New York: W.W. Norton \& Company, 1965), pp. 7-9.

71 Boethius, Consolation of Philosophy, book III, part XII, lines 45 to 58 .

72 Jacopo Peri, Euridice, scene 5, pp. xxxv and xxxvi. 
ure and the attainment of spiritual bliss. This idea is expressed in Aminta's versi sciolti ('Only the person who can count the stars in Heaven'; 'Chi può del Cielo annoverar le stelle'), ${ }^{73}$ which seem to answer Tirsi's lyrical description of the lovers' bliss in scene 2 ('With the pure ardour of the most beautiful star'; 'Nel pur ardor della piu bella stella'). Aminta's verses underscore that the newly reunited lovers share the blissful 'joys of paradise' ('i ben di paradiso'), first alluding quite clearly to a form of sexual fulfilment by underscoring the rosiness of Euridice's cheeks, a sign of her moral happiness and physical well-being, and a possible allusion to the consumption of her marriage with Orfeo. ${ }^{74}$ But Aminta's lines also link the happiness of the newly-wed couple, presumably found in sensual enjoyment, to the creation of universal harmony: as the lovers reunite, 'All souls and hearts are made happy', boasts Aminta, 'And through the serene air | Harmonious choirs are heard, | The sweet songs of winged cupids. ${ }^{75}$ In fact, as the resurrection of Euridice is in process, it is this very 'heavenly harmony' ('alt' armonia') — by which Aminta himself confesses to have been made supremely 'happy' ('lieto') — that, he believes, is his primary duty to proclaim to the world. This repeated insistence on that the fact that universal harmony is created through the sensual love of two worldly creatures is only superficially Ficinian in its connotations, for it does not suggest that spiritual bliss will or should always overcome and undo material pleasure. Rather, the aria points audaciously to a kind of spiritualisation of the material (in this case physical beauty and sensuous enjoyment, be it in the body of Euridice or in the sound of music itself), going so far as to suggest a sacralisation of the central physical pleasures of men's mundane lives. Indeed, not only sensual experience but also mundane existence gain a form of legitimacy and authority through Euridice's resurrection, precisely because the pleasures they have to offer (in love, art, and friendship) can sometimes make them comparable to true spiritual bliss.

This attempt to sacralise the material world and the experiences it provides is also most probably what was being staged in the final triumph of Orfeo, which would have simultaneously appeared to the opera's original audience

73 Ibid., scene 5, p. xxxiv.

74 Ibid.: 'Qual pallidetto giglio | Dolcement'or languia la bella sposa, | Or qual purpurea rosa | Il bel volto di lei venia vermiglio.' On the coded significance of the rosy cheeks of the bride in epithalamia, see Carter, 'Epyllia and Epithalamia', p. 11.

75 Jacopo Peri, Euridice, scene 5, p. xxxiv: 'Ma sempre' o che il bel ciglio | Chinasse a terra, ò rivolgess'in giro | L'alme beava, e i cor d'alto martiro, | Ardea la terra, ardean gl'eterni giri, | Ai gioiosi sospiri | Dell'uno, e l'altro innamorato core | E per l'aer sereno | S'udian musici cori | Dolci canti temprar d'alati amori. | Io fra l'alta armonia | Per far liet' ancor voi mi mess'in via.' 
as the triumph of Il Zazzerino, since Jacopo Peri (whose stage name this was) was singing Orfeo's dazzling part. For, in Euridice's last scene, Peri not only performed the role of its central male character; he also appeared as the principal virtuoso singer of the work as well as its main composer, skilfully uniting all three of these personae into a single figure in which the real or material could not be distinguished from the allegorical or spiritual. In Orfeo's elevation to the status of a demigod, moreover, his close association with both Apollo and Venus - the most worldly of all the pagan gods - played a central role. As such, Peri/Orfeo's triumph was the apotheosis of his very materiality, humanity, and sensuality (as character, singer, and composer).

\subsection{A Metadiscourse on the Spirituality of Spectacle}

In this respect, Rinuccini's allegorical discourse on the spirituality of pleasure can also be read as a meta-discourse on the pleasures and spiritual value of the divertimento itself. Rinuccini dwells at length, in his work, on the various reversals he has introduced into his plot, most probably following the example of the Alterati who, in their work on Aristotle's Poetics, had often foregrounded the role of reversal in the creation of dramatic pleasure. The last scene of the opera is particularly revealing from this point of view, as it works carefully to bring the spectator back to the pastoral scene of joyful pleasure with which the opera had opened. At first, the shepherds are still worried about the fate of Orfeo and Euridice, but Aminta soon announces happily that dolcezza (sweetness) and gioia (joy) are once again in Orfeo's heart and that Euridice will soon reappear. ${ }^{76}$ The shepherds initially remain incredulous, but, as Aminta further tells of the miraculous return of Orfeo and his bride to earth, they voice simultaneous 'stupore' and 'diletto' ('Think, by what stupor, what delight | Our souls and our hearts are engulfed | At the sweet sight of the happy couple'; 'Pensa di qual stupor, di qual diletto | Ingombrò l'alm'e, e i cori | Della felice coppia il dolce aspetto') $\cdot{ }^{77}$ Neither the audience nor the shepherds on the stage initially see this spectacular miracle, however-much in the same way that, earlier in the libretto, Rinuccini had refrained from explicitly staging the descent of Venus to earth to assist Orfeo in his voyage to Inferno, in order to leave room for the audience to imagine the deity and to contemplate the complex allegorical meanings attached to her in the plot. In scene 5, similarly, the shepherds' words do not only express their own astonishment and pleasure at imagining the couple's return to life; they also meta-discursively point to — and therefore simultaneously work to frame- the audience's experience of the melodrama,

76 Jacopo Peri, Euridice, scene 5, p. xxxiv.

77 Ibid. 
by asking the spectator to imagine the effect produced by an event that he or she cannot (yet) witness.

Although these ostensive delays in the actual representation of a miraculous action may have been intended at first to make the use of staging machines unnecessary, since macchine were probably not available in the room in which Euridice was performed, they also point to meta-theatrical meanings. For example, when Euridice appears at long last on the scene, she seems at first the product of a collective effort, both on stage and among the spectators, to envision her glorious return to life. As such, Euridice implicitly becomes the emblematic incarnation of a communion in pleasure, imagination, and belief, during which the audience is constantly called upon to indulge in the experience of its own senses, thereby participating actively in the creation of the power and fascination of the drama's most central scenes. In scene 5 , the collective production of this dramatic experience continues to be allegorically underscored in the action by the way the nymphs greet Euridice upon her return: they at first doubt that she is real, touching her to make sure is not simply a spirit. Faced with their incredulity, Euridice insists that she is a body:

Per quest'aere giocondo

E vivo e spiro' anch'io

Mirate il mio crin biondo

E del bel volto mio

Mirate, donne, le sembianze antiche

Riconoscete omai gl'usati accenti,

Udite il suon di queste voci amiche.

This happy air

I, too, live in and breathe:

Look at my blond locks,

Look, ladies, at the familiar features

Of my beautiful face;

Recognise again the accents of my speech,

Listen to the sound of my friendly words. ${ }^{78}$

As she comes to embody the intermingling of literal and figurative meanings in the opera's intricate plot, Euridice is not only portrayed as being as believable (and verisimilar) as the miracle she incarnates. She is also depicted as

78 Ibid., scene 5, p. xxxv. 
simultaneously carnal and spiritual-just like, one suspects, the spectacle itself would be understood to be, in the eyes of both Peri and Rinuccini. ${ }^{79}$

In other words, the apparition of Venus and the resurrection of Euridice were also meant to be read, in meta-theatrical terms, as an affirmation both of the spiritual value of spectacle and of the sensual pleasures it provokes (sight, hearing, imagination, etc.). Interestingly enough, a number of the remarks contemporary spectators are reported to have made about Euridice suggest that its daring stance on the spirituality of worldly pleasures was clearly perceived (though not always approved of) by its contemporary audience(s). We know of such remarks through two letters that Emilio de' Cavalieri wrote from Rome to Grand Ducal Secretary Marcello Accolti in the year 16oo. On 7 April 160o, Cavalieri reported that many Florentines in Rome had heard word of 'a new pastoral which Jacopo Corsi has in preparation' and which promises to be a 'heavenly thing. Cavalieri adds, with some irony, 'I pity the Heavens and the angels for being submitted to such parallels!' ${ }^{\prime 0}$ These words suggest that rumour had it in Florence that Peri was trying to write a work of a new type-a form of courtly divertimento that could rival in beauty devotional music itself, and that had the implicit aim of emphasising the spiritual value of the pleasures that were understood to be at the centre of courtly life (love, music, and dance). A similar conclusion can be drawn from a set of remarks Cavalieri made after the wedding ceremonies had ended, at a moment when it had become increasingly evident that he was losing the favour of Ferdinando. These remarks are contained in a post scriptum to a letter Cavalieri sent to Accolti on 24 November 1600, and were marked as intended for the secretary alone, rather than for his master. ${ }^{81}$ In this post scriptum, Cavalieri compares what he characterises as the failure of Peri's Euridice and Caccini's Cefalo with the success of his own Rappresentatione in the Oratorio della Vallicella at the beginning of 1600 , listing two causes for his rivals' difficulties. First, some of their wording was unsuitable for a proper 'tragic' plot, and this led to the staging of inappropriate topics ('quelle parole poche che lui ha fatte portano

79 Ibid., scene 5, p. xxxviii.

8o This letter was transcribed and published by Kirkendale, Emilio de' Cavalieri, pp. $3^{65}-66$ : 'Si è dato conto già a molti fiorentini di une pastorale nuova che fa il S.r Jacomo [sic] Corsi, che dicono che sarrà cosa celeste. Scrivo le stesse parole che me vien detto. Poveri cieli et angeli a che pararelli [=paralleli] si mettono.'

81 The complete text is in Kirkendale, Emilio de' Cavalieri, pp. 371-73. An English translation can be found in Claude Palisca, 'Musical Asides in the Diplomatic Correspondence of Emilio de' Cavalieri', Musical Quarterly, 49.3 (1963), pp. 339-55, (pp. 351-52). This article is reprinted in Palisca, Studies in the History of Italian Music and Music Theory, pp. 389-404. 
l'honore di tutte, et non intrare in parole tragiche, e soggeti da potervi appore'), by which Cavalieri clearly meant subjects that could not suitably allegorize the Medici or the event at hand. Second, the tonality of their works was an issue. Cavalieri claimed, in particular, that, among the Roman spectators he had questioned, the manner of these divertimenti had been thought unbefitting to the circumstances because they reminded courtly audiences too much of the ring and feel of devotional music:

In Roma non si adula. Et con quanti ho parlato, di ogni grado di persona, tutti me hanno detto che le comedie non sono riuscite, et in particolare la grande, et che le musiche sono state tediose, et che lì è parso sentire cantare la Passione. Et in particolare è stato detto del Marchese de Riano, di questa Passione.

In Rome, one does not adulate. As many people of all ranks I have spoken to have said to me: the comedies [i.e., Euridice and Cefalo] did not succeed, and in particular the big one [Cefalo] did not. They said that the music was tedious and seemed like the chanting of the Passion. The Marchese di Riano, in particular, mentioned the Passion. ${ }^{82}$

According to Cavalieri, Peri (just as much as Caccini) was misguided in his efforts to adapt the tonalities of devotional music in stile recitativo to court culture, succeeding only in producing a spectacle that felt completely out of place. It is, however, highly probable that, given his rivalry with both composers, Cavalieri rephrased what he had heard to his own advantage in order to insist that - as the success of his Rappresentatione suggested-the tonalities of devotional music were best left to churches and religious institutions, where their spiritual aims could be adequately fulfilled. Cavalieri, whose sacred Rappresentatione unequivocally rejected worldly pleasures, was probably fundamentally in disagreement with Peri's efforts to spiritualize the diletti of love, music, and dance. Indeed, act I, scenes 4 and 5 of his Rappresentatione stage an exchange in which the Soul invites the Body to reject all forms of terrestrial diletto, which is denounced as vain and false, while Piacere, an allegory of pleasure, parades lasciviously with two of his minions to the sound of overtly profane Neapolitan dance melodies. ${ }^{83}$ Such elements suggest that Cavalieri

82 The translation is mine, using the more accurate transcription by Kirkendale, Emilio de' Cavalieri, p. 372.

83 The text of Cavalieri's libretto is reprinted in Kirkendale, Emilio de' Cavalieri, pp. 301-13 (see scenes 4 and 5, pp. 306-07). For an analysis of the dance music created to charac- 
would have had little taste, at least at this stage in his life, for mundane tunes aspiring to the spirituality of devotional compositions, preferring to hold court and devotional music entirely separate. But given that Cavalieri was a particularly well-informed participant of the artistically contentious wedding ceremonies of 1600, the words he reports on Euridice - if their meaning is not taken strictly in negative terms - also suggest that Peri's and Rinuccini's work, in its attempt to portray love, poetry, music, and dance as meaningful, noble, and even divine pleasures, was immediately understood at the time as a courtly (and even mundane) response to Cavalieri's Rappresentatione. This would explain Cavalieri's urge to debunk the entire project of producing a court divertimento with higher spiritual aspirations as well as his attempt describe the entire experiment as a failure, which it clearly was not (though only a handful of Florentine courtiers originally saw Euridice at court because of the relatively small size of the venue). Rather, Peri's music and Rinuccini's libretto rapidly became famous across Italy, where their divertimento subsequently inspired a number of operas centred on the figure of Orpheus, such as Monteverdi's Orfeo (Mantova, 1607).

The Spectacle of Art's Power, or How to Spin a Myth into the Figuration of One's Court Position

Euridice's effort to spiritualize the sensuous experience of drama set to music cannot, of course, be separated from the courtly context in which the opera was developed. In this sense alone, the ties binding this work to the political configuration in and for which it was originally produced are anything but anecdotal. Indeed, Euridice not only meditates on art's spiritual value; it also interrogates the power that artistic practices and productions can exercise in the material world, as well as on the political structures that rule over sublunary affairs. From this perspective, the opera also functions as an allegorical statement about the place of art in the social and political economy of the court. This statement originates from two court artists who are clearly aspiring to favour, but who do not seem inclined to servility: while the allegorical depiction of the relationship of art to political power proposed in Euridice does not shun patronage, it does claim a certain social and political autonomy for both art and artists, even in court settings. This autonomy is to be understood

terise Piacere, see Anne Piéjus, 'Un Théâtre de l'âme', in Le Noyau et l'écorce: les arts de l'allégorie $X V^{e}-X V I I{ }^{e}$ siècles, ed. by Colette Nativel (Paris: Somogy/Académie de France à Rome, 2009), pp. 355-71 (p. 362). 
as a consequence of art's composite nature and of its interaction with love in both its carnal manifestations and its spiritual potential. As a product of matter and emotion - as well as of the spirit and the intellect-art's cosmic force can overcome the power of men, laws, and institutions.

The complexities of the relationship between art, power, and love in Euridice are clarified in scene 4 of the opera, during which Orfeo, led and assisted by Venus, descends to Hades to beg Pluto to return Euridice to her husband. His plea is supported not only by a demonstration of the power of music, but also by an evocation of the supernatural force of love. Indeed, in order to convince Pluto to allow Euridice to return, literally and figuratively, to the land of the living, Orfeo reminds Pluto of how much he himself loves his wife Proserpina. ${ }^{84}$ Orfeo's plea is seconded by Proserpina herself who-in a move that cannot be found in Ovid, yet figures in Poliziano's Fabula di Orfeo-solemnly calls upon her husband to grant Orfeo his request in the name of the love he, Pluto, bears for her. ${ }^{85}$ Pluto is moved, but hesitant. He objects that he cannot possibly override the laws of his own kingdom, which require that no dead soul ever see the light of day again. These laws are of course the laws of nature, but Pluto describes them as the civil laws of Inferno, drafted by none other than himself. Orfeo begs again for mercy, insisting that pity is befitting to the noble heart, while Caronte (Charon) points out to his master that, as sovereign of Inferno, it is his prerogative to freely change the laws he himself has made however he wishes: 'O great King, make whatever laws you please' ('Fa' pur leggie, o gran Re, quanto a te piace'). ${ }^{86}$ Exercising absolute power over his realm while simultaneously giving in to the cosmic power of Orfeo's music, Pluto finally announces that 'pity' ('pietà') has conquered him and allows Euridice to leave the underworld. A chorus of the gods of Inferno subsequently celebrate the role of mercede (mercy) in this miraculous gesture, thus linking Pluto's act of compassion back to the charitable and loving figure of Venus.

Interestingly enough, in this scene Orfeo does not flatter Pluto. The petitioner does not even present the king with the kind of fawning discourse of courtship that a powerful ruler might expect. Orfeo does, however, plead with power, but in a way that does not compromise his own integrity. Rather, he attempts to kindle love in the king's heart-love in the sense of sympathy and empathy - and this he does solely with moving words and accompanying sorrowful tunes, as Pluto himself acknowledges when he gives in to Orfeo's desires: 'Let pity triumph today in the infernal fields, | And be the pride and glory of

\footnotetext{
84 Jacopo Peri, Euridice, scene 4, pp. xxix-xxx.

85 See Poliziano, Stance / Stanze et Fable d'Orphée / Fabula di Orfeo, p. 70.

86 Jacopo Peri, Euridice, scene 4, pp. xxx-xxxi.
} 
your tears, of your beautiful song' ('Trionfi oggi pietà ne' campi inferni, | E sia la gloria, e'l vanto | Delle lagrime tue, del tuo bel canto'). ${ }^{87}$ As such, Orfeo's approach to power is parallel to the strategies Peri, Rinuccini, and Corsi appear to have employed on the occasion of Maria's marriage - that is, to gain the respect of the Grand Duke and to make acceptable at court their understanding of art, without ever entirely submitting to the expectations Florentine rulers were accustomed to bringing to bear upon court artists. ${ }^{88}$

Indeed, though Euridice was clearly created in a court setting, the opera cannot convincingly be read as an allegorical praise of the Medici, as its plot displays practically no direct ties to the family's history. ${ }^{89}$ This particularity once again supports the notion that this divertimento was conceived as somewhat of an aside in the wedding ceremonies. The lack of overt Medici propaganda also suggests that, because this performance was financially independent-at least to some degree - and took place in a venue that was not the Medici's official court theatre in the Uffizi, its creators and patron believed that they possessed a fair amount of ideological leeway with respect to how they chose to handle the Medici's encomiastic needs. A recently found piece of archival evidence confirms this hypothesis: according to Richard Goldwaithe and Tim Carter, the 6 October 1600 performance of Euridice was actually not the first. ${ }^{90}$ Instead, a courtly staging of the opera was performed on 28 May 1600 in the Palazzo Pitti at the request of Christina of Lorraine. The performance took place in the salone of the apartment occupied by Falvia Peretti Orsini, the noble wife of

$87 \quad$ Ibid., scene 4, p. xxxi.

88 On the encomiastic uses of art among the Medici, see in particular Janet Cox-Rearick, Dynasty and Destiny in Medici Art: Pontormo, Leo X, and the Two Cosimos (Princeton: Princeton University Press, 1984).

89 Though Euridice could well represent Maria, it is difficult to associate Orfeo with Henry, who did not even come as far as Florence to claim his bride, while Orfeo miraculously rescued his from Inferno. Any association of Orfeo with Ferdinando is also fragile, as it can only be substantiated with elements external to the work itself. See Kelley Harness, 'Le tre Euridici: Characterization and Allegory in the Euridici of Peri and Caccini', $§ 7.2$ to 7.5, which brings in Agnolo Bronzino's famous portrait of Ferdinando's father, Cosimo I, as Orpheus, arguing that it provides a key to the meaning of Peri's work. The Portrait of Cosimo I de' Medici as Orpheus (1537-1539?) is currently held in the Philadelphia Museum of Art and shows Orfeo/Cosimo seated in the nude; it was probably a wedding gift intended for Eleonora of Toledo. The problem with this argument is that the portrait is of Cosimo, not Ferdinando, and is at least forty years older than Euridice.

9o Goldwaithe and Carter, Orpheus in the Marketplace, p. 113. The document is a brief note dated 9 June 1600 that contains very few details (ASF Guardaroba Medicea 1152, fol. 148). 
Virginio Orsini (1572-1615), second Duke of Bracciano, an active patron of the arts in late sixteenth-century Florence. ${ }^{91}$ This young duke was the son of one of Cosimo I's daughters, Isabella de' Medici, who was murdered by her husband for infidelity in 1576 . Orsini also had strong ties to the Alterati, whose gatherings he sometimes attended. ${ }^{92}$ The choice of his wife's apartment as the first venue in which to showcase Euridice echoes the choice of Don Antonio's lodgings for the October performance. All of these spaces were somewhat peripheral loci, which belonged (or had belonged) to Medici princes whose status at court was tangential, even though missions were occasionally awarded to them, and they disposed (though sometimes only for a time) of lodgings in the grand ducal residence. ${ }^{93}$ The repeated use of such venues suggests that Peri, Rinuccini, and possibly even Corsi himself not only also occupied a somewhat marginal position in the economy of the Medici court, but also were intent on

91 See Valerio Morucci, 'Poets and Musicians in the Roman-Florentine Circle of Virginio Orsini, Duke of Bracciano (1572-1615)', Early Music, advance access published 21 January 2015, doi:10.1093/em/cau131.

92 Orsini, then twenty-five-years old, was the dedicatee of a collection of academic orations given by Giacomini before the Alterati and published shortly before Giacomini's death: see Orationi e discorsi di Lorenzo Giacomini Tebalducci Malespini (Florence: Sermartelli, 1597). A letter written by the Alterato Cosimo Minerbetti in January 1613 to Cosimo II and his first secretary, Andreo Cioli, also testifies to the fact that the Duke of Bracciano was usually present on major Alterati occasions. In response to a specific enquiry, Minerbetti indicated: 'Sono stato hoggi dal Signor Giovan Battista Strozzi, per informarmi del particulare, che si desiderava da loro S.S. et egli mi ha detto, ch'il Signore Don Giovanni Medici, et il Signore Don Virgilio [sic] Orsini furono presenti l'anno 1596 all'oratione che recitò publicamente il Signore Lorenzo Giacomini nell'Accademia degl'Alterati sopra le lodi di Torquato Tasso, alla quale si trovò ancora l'istesso Signore Giovambattista [Strozzi].' ASF Mediceo del Principato 1351, fol. $34^{r-v}$. The presence of Don Virginio Orsini and Don Giovanni de' Medici at this semi-public occasion is quite revealing, since both of these Medici princes, like Don Antonio himself, held a marginal position at court (either because they were illegitimate Medici offspring or because they descended from delegitimized family members). The Alterati were clearly systematically cultivating court figures that were not among the most powerful and central members of the dynasty.

The frailty of these men's curial positions is exemplified in the trajectory of Don Giovanni de' Medici, on which see Brendan Dooley, A Mattress Maker's Daughter: The Renaissance Romance of Don Giovanni de' Medici and Livia Vernazza (Cambridge: Harvard University Press, 2014). Dooley shows how Don Giovanni's romance with Livia Vernazza quickly alienated him from the Medici court, making it necessary for him to settle in Venice. After Don Giovanni's death in Murano in 1621, the Grand Duke fiercely went after the copious fortune this wealthy Medici bastard had left his wife and their surviving son, and managed to take most of it back from Livia. 
remaining somewhat peripheral. In this respect, Euridice might also be read as a meta-theatrical production of yet another kind, namely as a performance allegorically reflecting on the outsider position its creators were defining for themselves and their art at court-precisely by means of their art itself. In this strictly contextual reading - which would have been no less familiar to early modern spectators than the broader philosophical readings considered above-Euridice becomes a theatrical figuration of the type of relationship to political power these poets, musicians, and patrons hoped both they and their crafts might maintain. But what kind of relationship, exactly, did these men imagine, and how was it different from the types of relationship between art and power that were the norm at the Medici court?

The answer to this question is primarily to be found in the final half of Euridice, in whose scenes the spiritual power of poetry and music, when supported by true and generous (or charitable) love, is represented as capable of swaying absolute power itself. Indeed, the fact that Orfeo's art manages to convince Pluto to change his own laws suggests that poetry and music, when practiced at the level of virtuosity, have greater insights into what is right - and greater power over not only men but also nature itself-than does political might. This is first and foremost because music and art are capable of recreating God's worldly creations. As such, they partake in divinity itself and even possess the power to harness the cosmic forces that rule the world-thus trumping, in certain circumstances, all forms of terrestrial power. Yet, although the opera stresses that artists possess, via their art, a might comparable only to God's own, Euridice does not suggest that poets and musicians should themselves become rulers. Rather, as does Orfeo with Pluto, they are to negotiate continuously with those in power so as to be free to impose not only their practices but also their views. Accordingly, Orfeo's status as a demigod and his quasi-immortality as a creator are emphasised during his triumph, through the superposition of his figure on that of Apollo:

Ma qual poi del sacro umore

Sparge il core

Tra i mortal può dirsi un Dio

Ei degl'anni il volto eterno

Prende a scherno

e la morte e il fosco oblio.

But he who nourishes his heart

With sacred humours

Can call himself a God upon men: 
He can spurn the eternal flight

Of the ages,

And death, and gloomy oblivion. ${ }^{94}$

For while the seven first stanzas of the finale appear to refer to Apollo (the 'biondo arcier' or 'blond Archer') and only the last mentions Orfeo, both figures actually overlap in Rinuccini's intricate verses, and this implicit superposition underscores Orfeo's triumph: though not himself deified, the bard is hyperbolically likened to the god who presides over music and art. Yet no political destiny is ever evoked as a possible future for Orfeo. This is particularly striking because the association of Orfeo with the figure of King David-who is often represented as ruling Israel through the chanting of his psalms - was quite common throughout the early modern period and might well have been expected by the Palazzo Pitti audience. Instead of invoking a political destiny for Orfeo, however, the opera's finale shows him conspicuously revelling in his own music and profoundly enjoying, on a spiritual level, the love he has just rescued from death: 'armed only with his lyre', he is above all depicted as a 'happy husband' ('lieto sposo') and is therefore interested only in carrying Euridice to the heavens. She is his 'palm' and his sole worldly 'trophy'; he displays no interest whatsoever in political might or in military victories. ${ }^{95}$

This last depiction of Orfeo insists on his independence, particularly vis-à-vis political power: once Pluto has been swayed into giving Orfeo the freedom to enjoy both his beloved and his music, the bard appears to prosper in his autonomy, through which the sensual and spiritual powers of his art can be cultivated outside of any social or political obligations, in association with the joys of love. From this perspective, Orfeo's situation with respect to political power at the end of Euridice mirrors that which Peri, Rinuccini, and Corsi were hoping to carve out for themselves when they imposed the staging of this work in a somewhat peripheral locus during Maria's wedding festivities. By way of Euridice itself, the artists indirectly proclaim that the ideal configuration is one in which political power bows to music, acknowledging its extraordinary capacities and bestowing upon it legitimacy, without insisting that it exist in encomiastic enslavement. In such a configuration, music, dance, and poetry serve the prince only as much as is needed for these activities to acquire the freedom they require to exist as independent skills and thereby procure the enjoyment that defines them as arts.

94 Jacopo Peri, Euridice, scene 5, p. xxxvii.

95 Ibid.: 'Ma che più? S'al negro lito | Scende ardito | Sol di cetra armato Orfeo, | E del regno tenebroso | Lieto sposo | Porta al ciel palma, e trofeo.' 
In other words, while artists are represented as acknowledging the power of important political actors in Euridice, they are shown to do it only enough to obtain the recognition and freedom that will allow their art to develop according to its own rules and necessities. Two separate spheres or regimes are therefore defined allegorically over the course of Euridice: that of political practice and that of artistic activity. These two spheres are clearly depicted by the opera as connected: they are in fact shown to be the product of a reciprocal exchange. ${ }^{96}$ But Euridice also stresses that these practices are fundamentally distinct in their goals and in their modes of functioning. This theoretical configuration was also echoed in practice by the behaviour of Peri, Rinuccini, and Corsi at court: while the creators of Euridice appeared to be courting the Medici with a sumptuous divertimento, they were simultaneously distancing themselves, as artists, from the rulers of Florence by circulating, within this very spectacle, conceptions of artistic practices that did not submit art exclusively to the needs of a patron.

Such understandings of art and of its relationship to political power were in all probability honed amid the Alterati. Indeed, members of the academy experimented at length, both collectively and individually, with the idea that art, though needing to respect the existing political framework, should not be subjected to short-term political goals. They also attempted to define a place for artistic practice that would provide artists the freedom to obey the rationality of their craft, rather than impose upon them the necessity to serve power. In particular, the Alterati stressed that creators should be granted the liberty to set, for their art, goals that they themselves felt were appropriate-goals that academy members generally understood to be the production of pleasure in the audience, along with the moral and cognitive benefits they believed were attached to the enjoyment of artistic productions. In many of these debates, the academicians also recognized that art must not infringe on moral and political rules, thus pointing, in matters of art and power, to a dual regime involving both independence and interaction.

A hitherto unpublished manuscript by Filippo Sassetti offers one of the best examples of these (occasionally laborious) efforts to sort out the respective places of politics, poetry, and poetics in the social and political context of the

96 For a description of a comparable exchange in early seventeenth-century France, see Christian Jouhaud, 'Power and Literature: The Terms of the Exchange (1624-1642)', in The Administration of Aesthetics: Censorship, Political Criticism, and the Public Sphere, ed. by Richard Burt (Minneapolis: University of Minnesota Press, 1994), pp. 35-82. 
Florentine città. $^{97}$ In this manuscript, which Sassetti probably drafted sometime between 1575 and 1577 but never finished, the academician attempts a linear commentary of Aristotle's Poetics in Italian. He seems to have aimed at sketching out a balanced model that would have allowed both for the implementation of good government and for a form of autonomy in artistic practice. In the first part of his commentary, Sassetti stresses that those who govern should always have ultimate authority over the activities of poets, lest artists produce something that could be detrimental to the commonwealth. ${ }^{98}$ However, in the second half of the manuscript, Sassetti defines poetics as a discourse aimed principally at assisting poets in the production of works of art that will be sources of pleasure as well as of knowledge for those who contemplate them (fols $119^{\mathrm{v}}-124^{\mathrm{r}}$ ). As such, he claims, poetics rather than politics must rule over poetry. Though this last claim may seem to contradict Sassetti's initial considerations, it was probably only meant to better underscore his aim of creating boundaries between art and politics. For saying that poetics (rather than politics) should rule over poetry, at the level of its production, is a way to secure an isolated and intervention-free place in which art can develop according to its own standards. In Sassetti's model, it is apparently up to magistrates or princes to decide which of the effects that poetry can produce might (or might not) be good for their subjects or citizens; up to preceptors of poetics like Aristotle to determine how those effects can be achieved to the correct

97 BR 1539 , fols $81^{r}-126^{v}$. The text bears no title but is clearly in Sassetti's hand, as is most of the rest of the codex.

98 See in particular вR 1539 , fols $82^{\mathrm{v}}-83^{\mathrm{r}}$ : 'Senza dubbio alcuno, poi che mostrato habbiamo che la poesia ha gran forza indisporre in questa o in quella maniera l'animo de cittadini i governatori o regolatori delle città i Magistrati e Principi, o coloro che alla tranquillità delle cittadi $[s i c]$ hanno riguardo, saranno coloro che impongono a Poeti che l'opere loro facciano questo e non quell'altro ufficio; imperoche a costoro s'appartiene il pensare alla tranquillità degl'animi de popoli; et alla felicità degli stati e delle Republiche, e questo e quello chi da Aristotile fu detto nel primo [libro] dell' [E]tica; che uno Artificio sovrano si ritrovava ; il quale della felicità teneva cura e la procacciava il Politico addomandandolo; al quale egli tutte le arti sottoposi come le servi alla signora lequali di procacciarle studiano quelle cose che ella comanda per il bene di sua signoria sara adunque l'arte Politica come Regina che chiede a Poeti suoi servi le Poesie che facciano certo e determinato uficio $[$ sic $] ;[\ldots]$ e si come nel dimonstrare a poeti a quale fine habbiano ad havere le poesie e sara principe e maggior sendo egli la cagione alla quale s'ordinano l'altre cose; cosi egli o d'altri nillo $[s i c]$ insegnare a' poeti il modo che tenere debbano, sara agli stessi poeti inferiore; avvenga che questi ammaestramenti siano a fine di quella poesia ritrovate; tale adunque sara l'ordine tra queste arti che la Politica sara la piu nobile e la principale come quella chi comanda; dopo a lei sara la Poesia, e nel terzo luogo si riporrà quelle faculta, chi dimostra a poeti in che maniera de[v]ono comporsi le Poesie.' 
degree; and up to poets to create satisfactory plays and poems according to the requirements of their art. This understanding is not fully explained by Sassetti, however, since he left his commentary unfinished - possibly because he became convinced that it was neither safe nor timely to circulate a text that developed an understanding of the relationship of political power to the arts which, in the contemporary Florentine context, could be understood as non-conformist.

Nevertheless, it is striking to observe how many of Sassetti's ideas found their way into a work like Euridice. This fact testifies to the continued circulation of Sassetti's manuscripts among the Alterati well after his departure for India (where he died in 1588 , at the age of 48 ) and to the powerful intellectual influence he exercised on the academy even after he was no longer a regular participant at its meetings. ${ }^{99}$ But the fact that Euridice's meta-discourse on the spiritual value of love, poetry, music, and dance so evidently echoes the aesthetic and ethical debates entered into by Sassetti before 1578 also suggests that, after Sassetti's departure for the Indies, other strategies were devised among the Alterati to work out the theoretical issues that interested them and to circulate their opinions on these politically sensitive topics among Florentine elites. As they moved from exclusion to inclusion at the Medici court, the Alterati also moved, in their literary and artistic production, from theory to fictionand from largely uncirculated direct speech to the publication of indirect but

99 Many traces of this fascination with Sassetti can be found in the Florentine archives. BML Ashb. 558.2, fol. $82^{\mathrm{r}}$, for instance, indicates that, on 27 January 1589 (1590), the academy celebrated the memory of Sassetti (who had recently died in Goa) in the presence of both academicians and outside guests: 'Furono all'Accademia gli Academici che si trovarono a Firenze: e s'introdusse buona quantità di forestieri. E l'Rinovellato alla loro presenza recitò l'oratione delle lodi dell'Assettato [Sassetti]: Doppo cio il Tenero lesse una sua ode sopra il medesimo soggetto: E l'Ottavio Rinuccini ne disse ancora egli un'altra fatta da lui nella stessa materia.' BNCF Palat. 497, fols $101^{\mathrm{r}}-116^{\mathrm{r}}$ contains a manuscript transcription of many of the texts written or collected for the occasion ('Orazione in lode di Filippo Sassetti morto in Goa nel 1588 di Luigi Alammani', fols $101^{\mathrm{r}}-113^{\mathrm{r}}$; 'Notizia del giorno e della sepoltura di Filippo Sassetti', fol. 113 ; 'L'epitafio latino [di. F. Sassetti] composto e mandato a Goa dal fratello Francesco Sassetti', fol. 113; 'Canzone di Ottavio Rinuccini in lode di Filippo Sassetti all Signor Michael Saladini' ('Tra questo chiaro horrore'), fols $114^{\mathrm{r}}-115^{\mathrm{r}}$; 'Tetrastici di G.B. Strozzi nella morte di Filippo Sassetti' ('Oltre i famosi termini d'Alcide'), fols $115^{\mathrm{r}}-116^{\mathrm{r}}$; 'Sonetto di G.B. Vechietti in morta di Filippo Sassetti' ('Lungi dal natio nido in strana terra'), fol. $116^{\mathrm{r}}$. By the time Sassetti died in India, Florentine elites more generally had a great interest in him and in his work-particularly his letters from India, of which numerous manuscript copies can still be found in Florence and beyond: see Filippo Sassetti, Lettere da vari paesi, 1570-1588, ed. by Vanni Bramanti (Milan: Longanesi \& C., 1970). 
widely diffused allegorical works. From this perspective, Peri and Rinuccini's melodrama could also be envisaged as a less didactic, rigid, and conspicuous manner through which to circulate, both within and beyond Florence, the understandings of art at which the Alterati had arrived, in theory, prior to 1595. By choosing a court allegory set to heavenly and genuinely innovative music as the vehicle for their theoretical conceptions, the academicians were not only insuring that their ideas would be exposed in a more flexible fashion; they were also endowing their convictions with distinction and grace. In other words, they were spinning their erudition into an object of courtly curiosity, desire, and pleasure, without giving up too many of the daring nuances they had come to explore and promote within their academic gatherings.

\section{4}

\section{Conclusion}

Understanding Euridice as one of the most successful products of the theoretical and artistic endeavours of the Accademia degli Alterati makes its formal innovations seem the least of its audacities. For the work's attempt to blend poetry, music, and dance into a spectacle that remained dramatic at its coreon the model of what classical drama was imagined to have been-may not have been, in fact, its chief novelty. Rather, Euridice offered the Florentine court a new type of dramatic experience wherein diction, harmony, and movement worked together to create a totalizing spectacle and generate the feelings of overwhelmedness, astonishment, and enthusiasm that the Alterati associated with meraviglia. While Tasso's Aminta and Guarini's Pastor Fido both advanced similar artistic goals, they did not involve music as did Euridice. Furthermore, the opera's experimentation with the theory and practice of court spectacle is far more innovative and provocative than in other contemporary spectacles. For Peri and Rinuccini's creation not only attempted to define the contours of a new courtly experience by integrating music; it also redefined the very place of such court divertimenti in the economy of the court—and it did so precisely by praising the power of music.

Court celebrations normally required that those in power (who were usually also the patrons of the festive works) be praised and glorified. But Euridice transformed the relatively rigid and codified genre of the court celebration into a collective activity that seems to have had much more to do-in the goals it defined for itself via allegory — with the public musical spectacles that would soon develop in Venetian playhouses than with the politically charged Florentine intermedi (or with the Elizabethan court masques). In this respect, it is perhaps not surprising that Peri went on to become a close collaborator 
of Claudio Monteverdi, whose operatic works embody the circulation of opera from the courts of northern Italy to the early public theatres of the Venetian Republic. ${ }^{100}$ The new kind of dramatic performance Peri and Rinuccini, via Euridice, contributed to defining aimed at producing individual enjoyment in a collective setting instead of generating allegiance to the power and worldview of those who ruled over (usually extremely selective) court audiences. This new purpose also brought with it an attempt to redefine the place of artists in the economy of power. Euridice made possible the voicing, at court, of a perspective that was not entirely that of the court, and allowed for the creation of what one might call an outsider-insider position. This position could offer, to artists who claimed it, not only a reasonable amount of freedom in court settings and but also a form of public recognition and visibility within these spaces-in the orbit of court culture, as it were, yet somewhat at a distance from it.

Finally, Euridice is also an important experiment-even a milestone-with respect to the staging and dissemination of specific theoretical understandings of Aristotle's Poetics. The court performances themselves, as well as the subsequent publication of Euridice in a set of luxurious book formats, brought into court culture many of the academic discussions to which the Alterati, as dutiful disciples of Vettori, had devoted so much of their time and energy. These publications allowed the work to circulate among a much wider audience, albeit in the guise of a fiction the allegorical meaning of which would have been difficult to reconstitute for anyone who was not already in the know. This type of circulation is very different from that of Giraldi's tragedy Orbecche or of Speroni's play Canace, which were also the products of intense speculations on the Poetics, but whose audiences mostly remained confined to the erudite (and often academic) readership among which the works were produced and subsequently debated. Euridice, on the other hand, explores a type of relationship between theory and fiction that is much closer to the one presupposed in the link between Tasso's Gerusalemme liberata and his discourses 'On the Art of Poetry' and 'On the Heroic Poem', or between Guarini's Pastor Fido and his Compendio on pastoral tragi-comedy. In both of these last instances, poetics were explicitly adapted to the value, needs, and desires of courtly audienceswhich constituted the central readership of both Tasso and Guarini-and were circulated as a gloss to works of fiction previously published. In the case of Euridice, however, only the work of fiction was circulated. The theory, interestingly enough, was withheld from courtly audiences and is preserved today only in unpublished manuscripts. Yet, the work itself was in fact theory set as

100 See Ellen Rosand, Opera in Seventeenth-Century Venice: The Creation of a Genre (Berkeley: University of California Press, 1991). 
fiction. As such, it attempted to offer its viewers (and readers) a supple and elegant allegorical spectacle that was meant not only to be enjoyed as a fable but also to be deciphered as a statement on art and on the social function of artists. This way of setting theory into fiction may well be Euridice's most profound novelty, both as dramatic experiment and as complex aesthetic experience proposed to early modern audiences. 